\title{
Shareholder Voting in Mergers and Acquisitions: Evidence from the UK
}

\author{
Yerzhan Tokbolat ${ }^{\mathrm{a}}$, Steve Thompson ${ }^{\mathrm{b}}$ and Hang Le ${ }^{\mathrm{b}}$ \\ ${ }^{a}$ Nottingham Business School, Nottingham Trent University, Nottingham, UK \\ ${ }^{\mathrm{b}}$ Nottingham University Business School, Nottingham, UK \\ Correspondence: yerzhan.tokbolat@ntu.ac.uk*
}

\begin{abstract}
This paper examines the determinants and consequences of shareholder voting on mergers and acquisitions using a sample of resolutions approved by shareholders of UK publicly listed firms from 1997 to 2015 . We find that dissent on M\&A resolutions is negatively related to bidder announcement returns and positively related to shareholders' general dissatisfaction towards the management. Shareholder dissent is an important predictor of the announcement returns of subsequent M\&A deals. We also report an increase in shareholder dissent after the 2007-2008 financial crisis.
\end{abstract}

Keywords: shareholder voting, mergers and acquisitions, director remuneration reports, financial crisis.

JEL classification: G30; G34; G01

We gratefully acknowledge helpful comments and suggestions by two anonymous referees, Konstantinos Stathopoulos, Jo Danbolt, Susanne Espenlaub, Ephraim Clark, Douglas Cumming, Sabur Mollah, Pouyan Foroughi and participants at the Second Early Career Researchers Conference on Corporate Governance (University of Nottingham, June 2017), Fourth Young Finance Scholars Conference (University of Sussex, June 2017), 31st British Academy of Management Annual Conference (University of Warwick, September 2017), Third International Corporate Governance Society Annual Conference (Luiss University, September 2017) and the 30th Australasian Finance and Banking Annual Conference (University of New South Wales, December 2017). 


\section{Introduction}

Shareholder empowerment is a key component of the recent corporate governance reforms (see, e.g. Yermack 2010; European Commission 2014). Since the very need for governance is usually predicated on the potential conflict of interests between a firm's management and its suppliers of capital (Tirole 2001), this may seem self-explanatory. The contrasting view is that shareholder empowerment is unlikely to generate effective participation among shareholders insofar as it fails to recognise the distinctive roles of managers and shareholders where managers make corporate decisions whilst shareholders can invest in numerous ventures within a diversified portfolio (Berle and Means 1932). In support of this position considerable empirical evidence suggests that, when empowered, most shareholders tend to back management decisions most of the time (e.g. Burch, Morgan, and Wolf 2004; Cai, Garner, and Walkling 2009; Iliev et al. 2015).

Compared to voting on other corporate matters such as director remuneration (Conyon and Sadler 2010; Gregory-Smith, Thompson, and Wright 2014), director elections (Cai, Garner, and Walkling 2009; Ertimur, Ferri, and Oesch 2018), poison pill repeal and board declassification (Gordon and Pound 1993; Cuñat, Gine, and Guadalupe 2012) shareholder empowerment in the form of voting on M\&As is relatively less explored. Yet, perhaps no other corporate decision has the potential to damage shareholder value as much as embarking on an unsuccessful acquisition (see Alexandridis, Mavrovitis, and Travlos (2012) and Betzer, Doumet, and Goergen (2015) for reviews on value implications of M\&As). Moreover, ever since Baumol (1959) acquisitions have been viewed as potential source of gains for sizemotivated management at the expense of shareholders.

In this paper, we study the determinants and consequences of shareholder voting on M\&A proposals of UK firms. The UK Listing Rules (LR 2015) require binding voting for all 
deals that have the potential to change the shareholders' economic interests in the company's assets or liabilities. This presents a unique setting to study voting on M\&A resolutions. Voting on M\&As in the US, the setting of most prior studies, is limited only to the fraction of deals that involves issuance of the acquirer's equity by more than $20 \%$ of the outstanding common stock (Burch, Morgan, and Wolf 2004). Our sample of voting by UK shareholders therefore includes a more comprehensive selection of M\&A deals subject to shareholder approval than previous studies.

To the best of our knowledge, our paper is also the first study that utilises the detailed information on the number of votes cast to directly measure shareholder dissent on UK acquisitions. A related paper, Becht, Polo, and Rossi (2016), documents that in the UK the average market reaction to announcements of deals that require voting is positive while the reaction to deals that do not require voting is negative. While this evidence supports the notion that mandatory voting on M\&A proposals imposes a binding constraint on the acquirers' management, it is silent on the variations in shareholder dissent and factors that may drive shareholders' voting decisions. By using the number of votes our paper documents and explains the variations in shareholder dissent across deals and over time.

We explain shareholder voting against M\&A proposals with their dissatisfaction with the proposed acquisitions and with the management in general. Given that the market reaction to $M \& A$ announcements reveals market-based valuation of the proposed deals and of acquirers as stand-alone (Grinblatt and Titman 2002; Hietala, Kaplan, and Robinson 2003) and motivations behind the deals (Betzer, Doumet, and Goergen 2015), we argue that shareholders are more likely to dissent if the market announcement reaction is not in favour of the deal. We find that shareholder dissent on M\&A resolutions decreases with the market announcement reactions during our period of study, 1997-2015. 
Voting against management initiated proposals is a governance mechanism for shareholders to express their concerns (Hillman et al. 2011) particularly where directors are perceived as inserting their power to extract excessive rents from shareholders (Fahlenbrach 2009). We propose that shareholders are more likely to dissent if they believe that directors set their own rewards beyond purely market-determined levels. We proxy shareholder discontent with the management with: i) the level of excess director compensation and ii) shareholder dissent on the director remuneration reports (DRRs) prior to the M\&A proposals. We find that shareholder dissent on M\&A resolutions increases with the level of excess director remuneration and with prior dissent on DRRs. To the best of our knowledge, no prior study considers shareholder general satisfaction with the management or with the management compensation in the M\&A voting context.

We contribute to the growing strand of literature that evaluates the consequences of voting. The effectiveness of shareholder empowerment has been questioned given the low average level of shareholder dissent and the limited number of cases where voting has altered the outcome (Conyon and Sadler 2010; Iliev et al. 2015; Sauerwald, Van Oosterhout, and Van Essen 2016). However, disapproval expressed in director elections could be followed by immediate actions to avoid further embarrassment because of its reputational damage (Grundfest 1993). Cai, Garner, and Walkling (2009) report that lower approval vote of director elections could lead to subsequent CEO turnover while Fischer et al. (2009) show that it could also lead to better value acquisitions and divestitures. Our results suggest that higher shareholder dissent leads to lower abnormal returns around the announcement of subsequent deals. This indicates that shareholder dissent does not discipline managers to engage in better deals. Rather it serves as a source of information about the firm's acquisition strategy and management ability for shareholders and prospective investors to use in their investment decisions. 
The rest of the paper is structured as follows. The next section reviews the institutional background to shareholder voting regulations in the UK. We then provide a brief review of the current literature and develop the hypotheses. This is followed by the description of data, methodology and analysis of empirical results. Finally, we conclude by discussing the limitations of the study and provide recommendations for future research.

\section{Relevant literature and hypothesis development}

\subsection{Institutional background}

The interests of managers and shareholders may conflict in the acquisition decisions: the former, whether motivated by the desire for size-related rewards (Murphy 1999), or hubris (Roll 1986), may be more tolerant of high-risk or ill-advised deals than those shareholders who stand to bear their consequences. There is an abundant literature documenting value-destroying acquisitions (Danbolt 1995; Moeller, Schlingemann, and Stulz 2005; Alexandridis, Mavrovitis, and Travlos 2012), not least because managers may be rewarded for completing deals (Harford and Li 2007) even where these ultimately prove unsuccessful.

In a reflection of this, many countries have introduced - or are considering implementing - changes in corporate laws to protect shareholders by requiring a binding shareholder vote on proposed acquisitions. In the US, shareholder approval is necessary for deals involving the expansion of the acquirer's equity by more than $20 \%$ (Burch, Morgan, and Wolf 2004). Canada introduced a similar 25\% threshold in 2009 (Ontario Securities Commission 2009). The EU proposed changes to the Shareholder Rights Directive to require shareholder voting on significant related-party transactions in 2014 (European Commission 2014). Individual European countries, including Germany and France (Schult and Nikoleyczik 2012; Segain and Favier 2017) have also introduced directions on acquisition approval since the 2007-2008 global financial crisis. The Australian Stock Exchange began consulting on 
shareholder approval for selected takeovers in 2015 (Australian Stock Exchange 2015).

Unlike other countries, the UK requires companies with premium listing, i.e. those meeting the UK's highest standards of regulation and corporate governance, to call general meetings to approve deals that have the potential "to change the shareholders' economic interests in the company's assets or liabilities" (LR 2015, p. 166). That is, all the larger acquisitions (Class 1 deals) and a substantial proportion of other deals, including reverse takeovers and related-party transactions, are required to be approved by binding shareholder voting at Extraordinary General Meetings (EGMs). The intention is to encourage shareholders, as owners, to ratify and monitor their agents' decisions to protect themselves from selfinterested managers (see Appendix A for a summary of the UK Listing Rules). This means the shareholder approval requirement in the UK applies to significantly more variety of deals compared to other countries such as the US and Canada where the requirement for shareholder approval for M\&As depends on how a deal is financed.

Despite the institutional framework for shareholder empowerment, shareholder approval may confer unwelcome costs, which may lead to shareholders opt out of active participation. Unconvinced shareholders with liquid positions may prefer exit (Parrino, Sias, and Starks 2003) whilst the majority vote with management. Empirical literature on 'say-onpay' votes (Conyon and Sadler 2010; Ferri and Maber 2013; Gregory-Smith, Thompson, and Wright 2014) supports this as do the findings of Goergen and Renneboog (2001) that institutional investors tend to follow a passive strategy. Overturned resolutions or those with significant levels of dissent are typically restricted to particularly egregious or controversial decisions ${ }^{1}$. During our period of study, the average magnitude of shareholder dissatisfaction as measured by the percentage of dissent votes is small ${ }^{2}$. But even if passive acquiescence is the 
default position for shareholders facing decisions, their option of expressing dissent may remain a useful constraint.

\subsection{What determine shareholder dissent on $M \& A$ proposals?}

In the presence of separation of control and ownership in modern corporations, voting is a mechanism for shareholders to communicate their approval/disapproval of the firm's management and governance. Voting might help improve governance structures and enable shareholders to realise the value destroyed by poor corporate governance structures (Bebchuk 2005). In the context of acquisition proposals, we assert that both discontent with the proposed acquisitions and a general dissatisfaction with the firm's activities and performance affect the decision to vote against such proposals.

In deciding whether to vote for or against a proposed M\&A, shareholders need information on the wealth effects of such proposal. Given it is difficult and costly for shareholders to acquire and/or verify information, undecided shareholders might find information entailed in the market reaction to M\&A announcements, which are readily available, useful. A negative market reaction to the M\&A announcement indicates that unconvinced shareholders prefer to vote with their feet while a positive reaction reveals that the market is in favour of the deal.

The market reaction could also reveal information about the value of acquirers as standalone, i.e. a market re-assessment of the acquirer's value (Grinblatt and Titman 2002; Hietala, Kaplan, and Robinson 2003). Betzer, Doumet, and Goergen (2015) document that deals with positive market reaction to announcements, either accompanied by positive or negative longrun accounting performance, appear to have shareholder value increasing motives whereas deals with negative market reaction to announcements are motivated by acquirers' stock 
overvaluation, or agency and/or hubris problems where managers invest in value-destroying acquisitions. Thus, the market reaction could provide information about the value of the acquirer and whether the management pursues self-interest at the expense of shareholders. We, therefore, hypothesise that shareholders are more likely to dissent if the market, as reflected in the announcement reaction, is not in favour of the deal.

Hypothesis 1: The level of dissent on M\&A proposals decreases with the acquirer' abnormal announcement return.

Shareholders' willingness to support or to dissent on a proposal may also depend on their general (dis)satisfaction with the management and governance structures. Voting against management-initiated proposals expresses governance concerns (McCahery, Sautner, and Starks 2016; Hillman et al. 2011) particularly over managerial entrenchment (Cai, Garner, and Walkling 2009; Iliev et al. 2015). Excessive pay is often associated with weak governance structures where directors push their own rewards beyond purely market-determined levels (Fahlenbrach 2009; Gregory-Smith, Thompson, and Wright 2014). Bebchuk and Fried (2003, 2006) argue that the management's ability to influence their pay not only imposes substantial costs on shareholders but also signals their power and the extent of their rent extraction. Here we posit that shareholders may consider signalling their discontent through votes on M\&A proposals if they are unhappy with the excess rents captured by the management, particularly if they already express their view in a previous remuneration proposal.

Hypothesis 2a: The level of dissent on M\&A proposals increases with the level of excess director compensation of the acquirer.

Hypothesis 2b: The level of dissent on M\&A proposals increases with the level of shareholder dissent on director remuneration reports of the acquirer. 


\subsection{Shareholder dissent and subsequent M\&As}

Although voting is seen as the next best alternative means for securing shareholders' claims on residual returns (Fama and Jensen 1983), voting against company resolutions may be a doubleedged sword for unconvinced shareholders. Large negative votes arguably undermine executive authority and potentially destabilise management to the detriment of shareholder value (Gregory-Smith and Main 2014). This view appears to be supported by the low level of shareholder dissent recorded in the US and the UK (Burch, Morgan, and Wolf 2004; Conyon and Sadler 2010; Iliev et al. 2015).

Despite the fact that voting against a proposal may not always bring the outcomes that dissident shareholders desire, such voting can be expressive (Sauerwald, Van Oosterhout, and Van Essen 2016) and lead to subsequent governance and leadership changes (e.g. Cai, Garner, and Walkling 2009; Fischer et al. 2009). Fischer et al. (2009) document that shareholder dissatisfaction as indicated in lower vote approval on director elections could lead to fewer and better market-reaction acquisitions. In a similar vein, higher dissent on previous M\&A proposals may impede managers from engaging in value-destructing deals, thus leading to better deals being proposed and consequently higher market reaction to deal announcements.

However, one can argue that shareholder disapproval expressed via voting on M\&A deals sends a signal to the market, questioning the management's ability to identify and negotiate value-creating deals, thus making external financiers reluctant to accept subsequent acquisitions. In this context, the market may not receive subsequent deals favourably if there is high dissent on previous proposals. These two competing effects may not be mutually exclusive and thus the net impact of previous dissent on subsequent M\&As is ultimately an empirical question. Hence we propose two competing hypotheses: 
Hypothesis 3a: Higher dissent on the previous M\&A proposal leads to higher acquirer's announcement return on subsequent M\&A deals.

Hypothesis 3b: Higher dissent on the previous M\&A proposal leads to lower acquirer's announcement return on subsequent M\&A deals.

\section{Data and empirical methods}

\subsection{Data sources}

To study the determinants and consequences of shareholder voting on M\&A proposals we use a sample of M\&A deals by UK listed firms during 1997-2015 that require shareholder approval. This includes Class 1, reverse and related-party deals as classified in the UK Listing Rules. Data on the deal characteristics were collected from Thomson One. Financial and accounting data of bidders are from Datastream. Data on CEO compensation from 1999 to 2015 were collected from BoardEx. Data on compensation from 1997 to 1999 were collected manually from annual reports.

Data on voting for M\&A deals that took place from 1997 to 2009 were obtained from the proxy voting agency Manifest $\operatorname{Ltd}^{3}$. Data on voting for M\&A deals that took place from 2009 to 2015 were hand collected. To do this, we first downloaded all M\&A deals announced by UK listed firms between 2009 and 2015 from Thomson One. We then deleted deals for which financial, accounting data and deal characteristics were missing. Finally, we checked every deal for the requirement of approval with the Regulatory News Services (RNS), company websites, and business press. When approval was required we collected the votes of EGM meetings. Approval results of acquisitions from 1997 to 2009 were also manually checked with these sources.

We require that for each M\&A deal, data on company name, EGM date, resolution narrative, details of votes cast are available. Data on voting on directors' remunerations resolutions were also obtained from Manifest for the period 1997-2009 and manually collected 
for the period 2009-2015. Our final sample consists of 362 M\&A resolutions voted at the EGM of the acquiring company shareholders, including 309 Class 1 acquisitions, 31 related-party acquisitions, and 22 reverse takeovers ${ }^{4}$. In our sample the minimum transaction value is $£ 3$ million, there are 15 'remaining interest' deals and 177 cross-border deals.

To explore if deals that never reach an EGM and later are withdrawn are due to shareholder outrage, we downloaded withdrawn deals from Thomson One and examined news items and company websites. There are twelve such deals but only one was terminated because of shareholder outrage ${ }^{5}$. Other deals were withdrawn for reasons such as not agreeing with the target on a revised offer (7), losing to a rival firm (3), and not securing valid acceptances of target shares (1). Abnormal returns for these deals are not statistically significant from zero.

\subsection{Empirical methods}

This paper seeks to explain shareholder dissent (Dissent), measured as the number of votes cast 'against' as a percentage of total number of votes cast, using the probit model due to the bounded nature of Dissent (Papke and Wooldridge 1996). To examine the impact of the market reaction to $\mathrm{M} \& \mathrm{~A}$ announcements on dissent we measure $C A R(-1 ; 1)$ as the 3 -day cumulative abnormal returns around announcement date using the event-study methodology based on the market model. Here the market return is return on the FTSE All Share Index and the estimation period is 150 trading days $(-180,-30)$ relative to the announcement.

To study the influence of shareholders' overall (dis)satisfaction with the management on shareholder voting on M\&A proposals, we use two proxies: i) excess compensation Excess Total Comp ${ }^{6}$ and ii) shareholder dissent on previous director remuneration reports DissentDRR.

We measure Excess Total Comp as the difference between observed and predicted CEO total compensation. The predicted value was obtained from the regression of CEO total 
compensation against its determinants together with year and industry controls as in (Core, Guay, and Larcker 2008; Feito-Ruiz and Renneboog 2017). CEO total compensation is the log of the sum of cash compensation and equity-linked compensation both measured in $£ 000$ s at the fiscal year end prior to the announcement of M\&As.

DissentDRR is measured as the number of votes 'against' as a percentage of total votes cast on director remuneration reports prior to the M\&A proposal. For example, the acquisition of Wilson Bowden plc by Barratt Developments plc announced on 5 February 2007 was voted upon at the EGM held on 27 March 2007. We obtained the results of the most recent AGM, which was held on 28 November 2006 to approve the remuneration report for the year ended 30 June 2006. We do not have data on DissentDRR for some of the deals prior to 2003 because approval of remuneration reports only became mandatory for firms incorporated under the UK company law from 2003 (Department of Trade and Industry 2002).

We control for several firm characteristics that might affect shareholder dissent. Shareholder dissent might increase with Firm Size, measured as the natural logarithm of book value of sales, because management entrenchment in larger firms may be more severe (Masulis, Wang, and Xie 2007) and therefore deals by these firms may be deemed value destroying. Indeed, Moeller, Schlingemann, and Stulz (2004) find a negative relationship between firm size and announcement abnormal returns. They further find that larger firms pay higher premiums and make acquisitions that produce negative dollar synergies and explain this as the evidence of managerial hubris. However, higher shareholder dissatisfaction could be the result of more engagement between shareholders and management in larger companies, especially following the onset of the financial crisis (FRC 2013). We also control for other firm characteristics including Tobin's $q, R O A$, cash reserves and leverage scaled by total assets (Cash/TA and Leverage). 
We also control for deal characteristics. Diversifying is measured as a dummy variable set to 1 if acquirer and target firms' 2-digit SIC codes are different, 0 otherwise. Managers may want to run a larger diversified firm to have more prestige (Jensen 1986) and higher pay (Jensen and Murphy 1990) at the expense of shareholders. Morck, Shleifer, and Vishny (1990) and Graham, Lemmon, and Wolf (2002) find a negative relationship between diversifying acquisitions and shareholder value. Dissent therefore may be higher for diversifying deals. Cash-payment is measured as a dummy variable set to 1 if a bid is financed by cash only, and 0 otherwise. Dissent could also be higher for deals that are financed by equity than by cash as the former result in the dilution of ownership (Mitchell, Pulvino, and Stafford 2004). Bethel and Gillan (2002), for example, find that shareholders do not support management pay-related proposals that lead to higher dilution. We also control for other deal characteristics including relative deal size, measured as the ratio of the deal size and bidder's total asset (Rel.Size), and whether it is a friendly deal (Friendly) or a cross-border deal (Cross-border).

We recognise that our estimation process may suffer from an endogeneity problem which, if present, could confound the results and yield biased and inconsistent estimates. Endogeneity may occur in our empirical analysis due to omitted variables that determine shareholder dissent on M\&A resolutions and at the same time are correlated with the market reaction to deal announcements and/or shareholder general (dis)satisfaction with the management. One may argue that shareholders of firms possessing a strong corporate governance system that discourages their management from the pursuit of value-destroying acquisitions are less likely to dissent on an M\&A resolution that the management puts forward and, moreover, the market will react more favourably to such deal. Strong corporate governance could also discourage the management from paying themselves excessively and therefore lower shareholder dissent on remuneration resolutions. To address this endogeneity concern, we control for several variables that are standard in the governance literature including 
the share ownership of the board and of the largest shareholder who is not a board member ${ }^{7}$, the number of directors on the board, the percentage of non-executive directors, the number of female directors and CEO age. Definition for all variables is in Appendix B.

\section{Empirical results}

\subsection{Shareholder voting on M\&As and executive pay during 1997-2015}

Panel A of Table 1 presents the yearly distribution of M\&A deals voted by acquirer shareholders, the average dissent on such deals, and the average AGM dissent on the DRRs prior to voting on M\&A deals. The numbers of M\&A and DRR approvals differ because approval of M\&As is required for companies listed on LSE regardless the country of incorporation while approval of the DRRs is only required for firms incorporated in the UK.

On average, the level of dissent on M\&A deals is low throughout the entire period, especially compared to the level of dissent on DRRs (0.76\% compared to 5.25\%). Although no deal was blocked by shareholder dissent, twenty three deals (6\% of the deals) received relatively high dissent, i.e. greater than $5 \%^{8}$. Intense public interest in 'fat cat bosses' pay' and the UK government's effort on curbing executive pay and narrowing the growing wage gap between bosses and workers (Financial Times 2017a, 2017b) could have encouraged higher dissent for DRR compared to M\&A resolutions.

Panel A also shows that there is a sharp increase in both dissent on M\&As and DRRs following the dot.com bubble and the financial crisis. Panel B shows that the average M\&A and DRR dissent in the post-crisis period is significantly higher than in the pre-crisis period. This is consistent with the proposition that the degree of discretion that shareholders leave to managers depends on the formers' perception of the business environment (Gregory-Smith, Thompson, and Wright 2014). As financial markets witnessed an angry reaction to corporate 
scandals during the crisis (Yermack 2010), regulatory reforms, including those on M\&A activities, have been implemented to protect shareholders' interests. For example, the UK Stewardship Code was introduced in 2010 with the purpose of encouraging good governance practice by institutional investors (FRC 2010). It was later reported that the level of engagement between investors and boards of UK listed companies has increased (FRC 2013). Engaging with the board to establish a dialogue may be seen as a precursor to more 'aggressive activist' strategies (Roberts 2014). Panel C presents the dissent distribution by the twelve Fama-French industries.

In Table 2, we report the dissent for completed and uncompleted deals (Panel A) and for deals with different time lapse between the deal announcements and the dates of the EGMs where the voting took place (Panel B). A very small fraction of deals were not completed (13 out of 362 announcements) and these have higher level of dissent on M\&A resolutions and on the DRRs (although statistically insignificant). The reasons for withdrawal are losing to rival firms (4); rejection by target firms (3); issues with the competition committee (3), not reaching acceptance level of the offer (2); and the bidder being acquired itself (1).

For nearly half of the deals (175 out of 362 announcements) the EGMs took place within one month from the deal announcement dates. These deals have higher level of shareholder approval than deals that took longer from the announcement date to the EGM, indicating that shareholders become more dissatisfied if it takes longer for a firm to organise the EGM to vote on the M\&A resolution. The average level of dissent in deals that take longer than three months for the voting to take place is about twice as much compared to deals where the voting takes place in less than one month from the announcement dates $(0.52 \%$ compared to $1.11 \%)$. 


\subsection{Market reaction to $M \& A$ announcements and shareholder voting}

Table 3 reports the M\&A abnormal announcement returns for bidders, measured as the difference between the realised return and the expected return using the standard event study methodology. Our sample is reduced to 350 because of insufficient share price data around the announcements for 12 deals. Panel A shows that, on average, the market reactions to the M\&A announcements are positive and statistically significant in all three-event windows. Panel B shows that the market reactions are higher in the post-crisis period than before and during crisis.

Results of the probit regressions that explain cross-sectional variations in shareholder dissent are presented in Table 4. Due to missing values in some control variables the number of observations is reduced to 338. Models (1) to (4) are estimated with the full sample while models (5) to (8) are estimated with the sample of Class 1 acquisitions only. In all models the marginal effect of $C A R(-1 ; 1)$ is negative and statistically significant. This result indicates that the higher the market evaluation of a deal the lower the shareholder dissent on the deal resolution, which provides strong support for our Hypothesis 1.

As predicted, deals by large firms and diversifying deals are associated with higher shareholder dissent. This is consistent with the findings reported previously that these deals generally are value destroying (Morck, Shleifer, and Vishny 1990; Moeller, Schlingemann, and Stulz 2004) and that shareholders are more likely to oppose the deals when managers enlarge firm scope at the expenses of shareholders (Berger and Ofek 1995; Ataullah et al. 2014) ${ }^{9}$. Deals with all cash payment receive less dissent compared to deals that are financed with equity, which is consistent with Bethel and Gillan (2002) findings that shareholders do not support management proposals that lead to higher dilution of ownership. We introduce a dummy variable Post-crisis in models (2), (4), (6) and (8) to control for the effect of the 2007-2008 financial crisis. The marginal effect of Post-crisis is positive and statistically significant in all 
specifications. This suggests that shareholder dissent is higher in the post-crisis period, which is consistent with the results reported in Table 1. Lastly, shareholder dissent is positively related to board size and CEO age and negatively related to the number of female directors and the share ownership of the directors.

\subsection{Shareholder dissatisfaction and dissent on $M \& A$ proposals}

We next examine if shareholder dissatisfaction towards the management, as proxied by excess CEO compensation (Excess Total Comp) and dissent on DRRs (DissentDRR), influences voting on M\&A resolutions. Table 5 reports excess CEO compensation of acquirers. Excess compensation in firms with higher than median (average) dissent on M\&A proposals is higher than that of acquirers with lower dissent but the difference is not statistically significant.

Table 6 presents the results of the probit regressions where we include excess compensation (Excess Total Comp) in models (1)-(4) and prior AGM DissentDRR in models (5)-(8) for the full sample. The sample size is reduced when we include DissentDRR because the approval of DRRs became mandatory only from 2003 and only for firms incorporated in the UK. The marginal effect of both Excess Total Comp and DissentDRR is positive and statistically significant in all models. This suggests that unhappy shareholders are willing to seize another opportunity to voice their governance concern about the management, particularly about entrenchment in the form of excess compensation at EGMs. Overall, our results provide supporting evidence for hypotheses $2 \mathrm{a}$ and $2 \mathrm{~b}$. The impact of $C A R(-1 ; 1)$ and other variables remain similar to that in Table 4 . We repeat the above exercise with the sample of only Class 1 acquisitions and yield qualitatively similar results.

\subsection{Shareholder dissent and market reaction to subsequent M\&As}


Panel A of Table 7 presents the number of M\&A announcements one year after the voting. About half of the M\&A deals are followed by the announcement of at least another deal and $23 \%$ of the deals are followed by two or more deals within one year after voting. We construct a sample of 253 first and second deals announced in the year following the voting of the original 362 deals. We divide the sample into two sub-samples, high- and low-dissented acquisitions based on the median and mean of the dissent on the original M\&As. The average market reaction to these deals and the results for the difference in the means/medians test are presented in Panel B. The results suggest that acquirers who receive higher dissent in the original deals experience statistically significantly lower abnormal announcement returns for their subsequent M\&A proposals.

Regressions results of the impact of dissent on the original deals on the announcement returns of subsequent M\&As are reported in Table 8 . The negative coefficient of Dissent suggests that firms with higher dissent experience lower announcement abnormal returns on subsequent M\&As. This is consistent with the non-parametric results in Table 7 and supports our Hypothesis $3 b$.

\section{Robustness tests}

We carry out a battery of robustness check to ensure that the reported results are not subject to our selected method of constructing the sample or variables. To address the concern that our results may be subject to measurement error in measuring shareholder dissent, we construct dissent in two alternative ways: i) Dissent2 as the number of votes cast 'against' as a percentage of the total number of votes that could be cast based on voting rights ${ }^{10}$; and ii) High Dissent equal to 1 when Dissent used in the original regressions is higher than the mean value of Dissent, 0 otherwise. The results using these measures of dissent are reported in Table 9. We also use the median Dissent to distinguish between highly and low dissented deals and the 
results (not reported for brevity) do not differ. Overall, we find that the main results in Table 4 are robust to different measures of shareholder dissent.

Next we use alternative measures of shareholder (dis)satisfaction: i) Excess Cash Comp and ii) Resid.DRR. We measure Excess Cash Comp in a similar fashion to Excess Total Comp using only the cash element of CEO compensation. Similar to Cai, Garner, and Walkling (2009), we apply a two-stage regression analysis: we first regress DissentDRR against all firmspecific variables in Table 4; we then take the residuals from this regression (Resid.DRR) and use them as an independent variable in the second stage of the regression. This is to address the potential problem of endogeneity: both voting decisions (on M\&As and on DRRs) may be determined by the same factors because DissentDRR is potentially a function of some characteristics already included in the regression. Results reported in Table 10 are similar to results in Table 6 where we use Excess Total Comp and DissentDRR.

To address a potential problem of endogeneity in Table 8, we regress Dissent on its significant determinants found in Table 4 and use the residual dissent (Res.Dissent) from the regression to explain the announcement returns of subsequent M\&As. The findings presented in Table 11 are not different to the results in Table 8.

\section{Conclusion}

Findings presented in this paper are initial steps in our effort to understand what information shareholders in the UK take into account when casting votes on M\&A resolutions and whether the votes are predictive of the valuation of subsequent M\&A announcements. We show that shareholder dissent decreases with abnormal stock return at the announcement, suggesting that if the market sentiment to the deal is favourable then shareholders are less likely to vote against the deal. Shareholders also support acquisitions financed though cash, i.e. they are against 
equity-financed deals that will lead to ownership dilution. Shareholder dissent is higher on diversifying M\&As and increases with bidder size. This is consistent with the evidence that (at least some) shareholders consider diversification to be a value-destroying strategy. More importantly, we find that shareholders already dissatisfied with their management, in particular with the management compensation will cast more votes against the M\&A proposals and that acquirers with highly dissented deals receive lower abnormal announcement returns on their subsequent M\&As.

The changes in the regulations on M\&A activities and corporate governance around the world have led to some developments in shareholder and investor activism in the post-crisis period. In the UK, it has been argued that the activism has gone beyond pure executive remuneration issues (Roberts 2014). Although there is a significant increase in dissent on M\&As in the post-crisis period, our findings suggest that on average shareholders have rather been reluctant to vote against acquisitions. One limitation of this study is that we are unable to distinguish between individual and institutional voting. Are institutional shareholders any different to private shareholders in their voting patterns? Are they more likely to vote with their feet? Now, data on institutional voting is at best patchy as disclosure of voting outcomes by institutional investors is voluntary. However, the Companies Act 2006 empowers the UK government to introduce regulations in the future that would allow more disclosure of institutional voting outcomes. When more data are available in the public domain, further insights into the voting on M\&A process should be achievable. It is certainly an interesting area for future research. 
Table 1. Sample distribution

\begin{tabular}{|c|c|c|c|c|}
\hline \multicolumn{5}{|c|}{ Panel A: Number of deals and average dissent by year } \\
\hline Year & $M \& A(n=362)$ & Dissent on M\&As (\%) & $\operatorname{DRR}(n=200)$ & Dissent on DRRs (\%) \\
\hline 1997 & 7 & 0.04 & - & - \\
\hline 1998 & 14 & 0.53 & - & - \\
\hline 1999 & 37 & 0.75 & 1 & 0.77 \\
\hline 2000 & 27 & 0.52 & 1 & 0.13 \\
\hline 2001 & 22 & 1.12 & - & - \\
\hline 2002 & 20 & 0.98 & 5 & 4.15 \\
\hline 2003 & 25 & 0.40 & 14 & 3.60 \\
\hline 2004 & 25 & 0.21 & 25 & 5.81 \\
\hline 2005 & 25 & 0.61 & 23 & 5.15 \\
\hline 2006 & 28 & 0.59 & 25 & 7.21 \\
\hline 2007 & 30 & 0.58 & 26 & 2.80 \\
\hline 2008 & 16 & 0.33 & 14 & 1.77 \\
\hline 2009 & 11 & 2.17 & 6 & 4.62 \\
\hline 2010 & 10 & 1.34 & 6 & 5.98 \\
\hline 2011 & 14 & 1.43 & 12 & 8.24 \\
\hline 2012 & 10 & 0.50 & 8 & 4.39 \\
\hline 2013 & 10 & 0.41 & 8 & 12.11 \\
\hline 2014 & 19 & 2.13 & 17 & 4.45 \\
\hline 2015 & 12 & 0.39 & 9 & 7.40 \\
\hline Average & 19 & 0.76 & 12.5 & 5.25 \\
\hline Median & - & 0.05 & - & 2.22 \\
\hline Std.Dev & - & 3.65 & - & 8.61 \\
\hline
\end{tabular}

\begin{tabular}{|c|c|c|c|}
\hline \multicolumn{4}{|c|}{ Panel B: Average dissent before and after crisis } \\
\hline Resolution & Pre-crisis (1997-2008) & Post-crisis (2009-2015) & t-statistics \\
\hline M\&A (n=276/86) & 0.60 & 1.30 & $\mathrm{t}=-2.452 * * *$ \\
\hline $\operatorname{DRR}(n=134 / 66)$ & 4.58 & 6.62 & $\mathrm{t}=-1.665^{* *}$ \\
\hline \multicolumn{4}{|c|}{ Panel C: Average dissent by industry } \\
\hline Industry & Dissent on M\&As (\%) & Industry & Dissent on M\&As (\%) \\
\hline Telecommunications & 1.84 & Nondurables & 0.65 \\
\hline Utilities & 1.42 & Business Equipment & 0.34 \\
\hline Chemicals & 1.16 & Healthcare & 0.28 \\
\hline Money & 1.09 & Manufacturing & 0.27 \\
\hline Other & 1.04 & Shops & 0.21 \\
\hline Energy & 0.90 & Durables & 0.06 \\
\hline \multicolumn{4}{|c|}{$\begin{array}{l}\text { Notes: Panel A presents the yearly distribution of the number of M\&A deals voted by acquirer shareholders and the level of } \\
\text { dissent in percentage terms. It also reports dissent on the DRRs in the AGM prior to voting on M\&A deals. Dissent is the } \\
\text { ratio of number of votes 'against' divided by number of 'turnout' votes. Panel B reports the average dissent on M\&A deals } \\
\text { and DRRs in the pre- and post-crisis periods. Panel C reports the average dissent on M\&A deals across Fama-French } 12 \\
\text { industry groups. The average dissent ratios in the pre- and post-crisis periods in Panel B are compared using a one-tailed t- } \\
\text { test. } * * * \text { and } * * * \text { denote that the post-crisis mean dissent is larger than the pre-crisis dissent at statistical significance of } \\
10 \%, 5 \% \text { and } 1 \% \text {, respectively. }\end{array}$} \\
\hline
\end{tabular}


Table 2. Shareholder dissent by completion status and time to voting

\begin{tabular}{|c|c|c|c|}
\hline \multicolumn{4}{|c|}{ Panel A: Average dissent by acquisition completion status (362 deals) } \\
\hline Resolution & Con & & Not completed \\
\hline M\&A & & & 1.135 \\
\hline (Number of deals) & & & $(15)$ \\
\hline DRR & & & 8.040 \\
\hline (Number of deals) & & & $(9)$ \\
\hline \multicolumn{4}{|c|}{ Panel B: Average dissent by the interval between announcement and EGM (362 deals) } \\
\hline Resolution & $<1$ month & 1 to 3 months & $>3$ months \\
\hline M\&A & 0.521 & $0.963 * *$ & $1.108 * *$ \\
\hline (Number of deals) & $(175)$ & $(150)$ & $(37)$ \\
\hline DRR & 5.211 & 5.109 & 6.012 \\
\hline (Number of deals) & $(85)$ & $(92)$ & $(23)$ \\
\hline
\end{tabular}

Notes: Panels A and B present the average dissent by acquisition completion status and the interval between M\&A announcement and EGM date, respectively. Differences in means in both panels are tested by a one-tailed t-test. $*, * *$ and $* * *$ denote statistical significance at $10 \%, 5 \%$ and $1 \%$, respectively.

Table 3. Cumulative abnormal returns for acquirers

\begin{tabular}{lllllll}
\hline \multicolumn{7}{l}{ Panel A. Average abnormal returns } \\
\hline Return & Mean & Std.Dev & Min & Median & Max & t-statistics \\
\hline$A R(0)$ & 0.015 & 0.069 & -0.199 & 0.007 & 0.334 & $4.215^{* * *}$ \\
$C A R(-1 ; 1)$ & 0.022 & 0.085 & -0.294 & 0.019 & 0.340 & $4.901 * * *$ \\
$C A R(-2 ; 2)$ & 0.024 & 0.093 & -0.454 & 0.017 & 0.469 & $4.860 * * *$ \\
$C A R(-3 ; 3)$ & 0.026 & 0.103 & -0.411 & 0.016 & 0.548 & $4.722 * * *$ \\
\hline
\end{tabular}

Panel B. Returns before and after crisis

\begin{tabular}{lccc}
\hline Return & Pre-crisis $(\mathrm{n}=265)$ & Post-crisis $(\mathrm{n}=85)$ & t-statistics \\
\hline$A R(0)$ & 0.012 & 0.027 & $-1.743^{* *}$ \\
$C A R(-1 ; 1)$ & 0.020 & 0.029 & -0.816 \\
$C A R(-2 ; 2)$ & 0.021 & 0.036 & $-1.306^{*}$ \\
$C A R(-3 ; 3)$ & 0.022 & 0.038 & -1.201 \\
\hline
\end{tabular}

Notes: Panel A reports abnormal returns for acquirers associated with the announcement of M\&A deals. Panel $\mathrm{B}$ compares the difference in the means of abnormal returns before and after crisis. Significance is tested using a two-tailed t-test for the hypothesis that abnormal returns are different from zero in Panel A and a one-tailed $\mathrm{t}$-test that the post crisis average abnormal returns are higher than the pre-crisis returns in Panel B. *, ** and $* * *$ denote statistical significance of $10 \%, 5 \%$ and $1 \%$, respectively. 
Table 4. Determinants of dissent on M\&A resolutions

\begin{tabular}{|c|c|c|c|c|c|c|c|c|}
\hline & $(1)$ & (2) & (3) & (4) & (5) & (6) & (7) & $(8)$ \\
\hline CAR $(-1 ; 1)$ & $\begin{array}{c}-0.042 * * * \\
(0.015)\end{array}$ & $\begin{array}{c}-0.034 * * \\
(0.015)\end{array}$ & $\begin{array}{c}-0.041 * * \\
(0.016)\end{array}$ & $\begin{array}{c}-0.033 * * \\
(0.016)\end{array}$ & $\begin{array}{c}-0.035 * * \\
(0.016)\end{array}$ & $\begin{array}{c}-0.032 * * \\
(0.016)\end{array}$ & $\begin{array}{c}-0.036^{* *} \\
(0.016)\end{array}$ & $\begin{array}{c}-0.032 * * \\
(0.016)\end{array}$ \\
\hline Firm Size & $\begin{array}{c}0.002 * * \\
(0.001)\end{array}$ & $\begin{array}{c}0.002 * * \\
(0.001)\end{array}$ & $\begin{array}{c}0.002 * * \\
(0.001)\end{array}$ & $\begin{array}{c}0.002 * * \\
(0.001)\end{array}$ & $\begin{array}{l}0.001 * \\
(0.001)\end{array}$ & $\begin{array}{c}0.002 * * \\
(0.001)\end{array}$ & $\begin{array}{c}0.001 \\
(0.001)\end{array}$ & $\begin{array}{l}0.001 * \\
(0.001)\end{array}$ \\
\hline Diversifying & $\begin{array}{l}0.005^{*} \\
(0.002)\end{array}$ & $\begin{array}{l}0.005^{*} \\
(0.003)\end{array}$ & $\begin{array}{c}0.005^{* *} \\
(0.002)\end{array}$ & $\begin{array}{c}0.005^{* *} \\
(0.002)\end{array}$ & $\begin{array}{c}0.005^{* *} \\
(0.002)\end{array}$ & $\begin{array}{l}0.005^{*} \\
(0.003)\end{array}$ & $\begin{array}{c}0.005^{* *} \\
(0.002)\end{array}$ & $\begin{array}{c}0.005^{* *} \\
(0.002)\end{array}$ \\
\hline Cash-payment & $\begin{array}{c}-0.004 * \\
(0.002)\end{array}$ & $\begin{array}{c}-0.005^{*} \\
(0.002)\end{array}$ & $\begin{array}{r}-0.004^{*} \\
(0.002)\end{array}$ & $\begin{array}{c}-0.005^{*} \\
(0.003)\end{array}$ & $\begin{array}{c}-0.004^{*} \\
(0.002)\end{array}$ & $\begin{array}{c}-0.005 * * \\
(0.003)\end{array}$ & $\begin{array}{c}-0.004^{*} \\
(0.002)\end{array}$ & $\begin{array}{c}-0.006^{* *} \\
(0.003)\end{array}$ \\
\hline BoardOwn & $\begin{array}{c}-0.000 * \\
(0.000)\end{array}$ & $\begin{array}{c}-0.000 * \\
(0.000)\end{array}$ & $\begin{array}{l}-0.000 \\
(0.000)\end{array}$ & $\begin{array}{l}-0.000 \\
(0.000)\end{array}$ & $\begin{array}{l}-0.000 \\
(0.000)\end{array}$ & $\begin{array}{l}-0.000 \\
(0.000)\end{array}$ & $\begin{array}{l}-0.000 \\
(0.000)\end{array}$ & $\begin{array}{l}-0.000 \\
(0.000)\end{array}$ \\
\hline OwnConc & $\begin{array}{c}0.000 \\
(0.000)\end{array}$ & $\begin{array}{c}0.000 \\
(0.000)\end{array}$ & $\begin{array}{c}0.000 \\
(0.000)\end{array}$ & $\begin{array}{l}-0.000 \\
(0.000)\end{array}$ & $\begin{array}{l}-0.000 \\
(0.000)\end{array}$ & $\begin{array}{l}-0.000 \\
(0.000)\end{array}$ & $\begin{array}{l}-0.000 \\
(0.000)\end{array}$ & $\begin{array}{l}-0.000 \\
(0.000)\end{array}$ \\
\hline Board Size & $\begin{array}{c}0.012^{* *} \\
(0.005)\end{array}$ & $\begin{array}{c}0.012^{* *} * \\
(0.005)\end{array}$ & $\begin{array}{c}0.013^{* *} * \\
(0.005)\end{array}$ & $\begin{array}{c}0.013^{* *} * \\
(0.005)\end{array}$ & $\begin{array}{c}0.014 * * * \\
(0.005)\end{array}$ & $\begin{array}{c}0.012 * * \\
(0.005)\end{array}$ & $\begin{array}{c}0.014 * * * \\
(0.005)\end{array}$ & $\begin{array}{c}0.011 * * \\
(0.005)\end{array}$ \\
\hline Non-Exec & $\begin{array}{c}0.007 \\
(0.006)\end{array}$ & $\begin{array}{c}0.007 \\
(0.007)\end{array}$ & $\begin{array}{c}0.008 \\
(0.007)\end{array}$ & $\begin{array}{c}0.007 \\
(0.006)\end{array}$ & $\begin{array}{c}0.005 \\
(0.006)\end{array}$ & $\begin{array}{c}0.007 \\
(0.008)\end{array}$ & $\begin{array}{c}0.005 \\
(0.006)\end{array}$ & $\begin{array}{c}0.006 \\
(0.006)\end{array}$ \\
\hline Gender & $\begin{array}{c}-0.005^{* * *} * \\
(0.002)\end{array}$ & $\begin{array}{c}-0.005^{* * *} * \\
(0.002)\end{array}$ & $\begin{array}{c}-0.005^{* * *} * \\
(0.002)\end{array}$ & $\begin{array}{c}-0.005^{* * *} * \\
(0.002)\end{array}$ & $\begin{array}{c}-0.006 * * * \\
(0.002)\end{array}$ & $\begin{array}{c}-0.004 * * * \\
(0.002)\end{array}$ & $\begin{array}{c}-0.005 * * * \\
(0.002)\end{array}$ & $\begin{array}{c}-0.004 * * \\
(0.002)\end{array}$ \\
\hline CEO Age & $\begin{array}{c}0.014 \\
(0.009)\end{array}$ & $\begin{array}{c}0.013 \\
(0.010)\end{array}$ & $\begin{array}{c}0.014 \\
(0.009)\end{array}$ & $\begin{array}{c}0.013 \\
(0.010)\end{array}$ & $\begin{array}{c}0.022 * * \\
(0.010)\end{array}$ & $\begin{array}{c}0.019 * * \\
(0.010)\end{array}$ & $\begin{array}{c}0.022 * * \\
(0.009)\end{array}$ & $\begin{array}{c}0.020 * * \\
(0.009)\end{array}$ \\
\hline$R O A$ & & & $\begin{array}{c}0.005 \\
(0.005)\end{array}$ & $\begin{array}{c}0.005 \\
(0.006)\end{array}$ & & & $\begin{array}{c}0.005 \\
(0.005)\end{array}$ & $\begin{array}{c}0.003 \\
(0.005)\end{array}$ \\
\hline Tobin's q & & & $\begin{array}{l}-0.001 \\
(0.001)\end{array}$ & $\begin{array}{c}-0.002 \\
(0.001)\end{array}$ & & & $\begin{array}{l}-0.001 \\
(0.001)\end{array}$ & $\begin{array}{l}-0.001 \\
(0.000)\end{array}$ \\
\hline Cash/TA & & & $\begin{array}{c}0.006 \\
(0.009)\end{array}$ & $\begin{array}{c}0.008 \\
(0.010)\end{array}$ & & & $\begin{array}{c}0.005 \\
(0.008)\end{array}$ & $\begin{array}{c}0.006 \\
(0.009)\end{array}$ \\
\hline Leverage & & & $\begin{array}{c}0.003 \\
(0.006)\end{array}$ & $\begin{array}{c}0.002 \\
(0.007)\end{array}$ & & & $\begin{array}{c}0.000 \\
(0.006)\end{array}$ & $\begin{array}{c}0.001 \\
(0.007)\end{array}$ \\
\hline Rel.Size & & & $\begin{array}{c}0.000 \\
(0.001)\end{array}$ & $\begin{array}{c}0.000 \\
(0.000)\end{array}$ & & & $\begin{array}{c}0.000 \\
(0.001)\end{array}$ & $\begin{array}{c}0.000 \\
(0.000)\end{array}$ \\
\hline Friendly & & & $\begin{array}{c}0.001 \\
(0.003)\end{array}$ & $\begin{array}{c}0.002 \\
(0.003)\end{array}$ & & & $\begin{array}{c}0.001 \\
(0.003)\end{array}$ & $\begin{array}{l}-0.000 \\
(0.003)\end{array}$ \\
\hline Cross-border & & & $\begin{array}{c}0.001 \\
(0.002)\end{array}$ & $\begin{array}{c}0.001 \\
(0.003)\end{array}$ & & & $\begin{array}{c}0.002 \\
(0.003)\end{array}$ & $\begin{array}{c}0.003 \\
(0.003)\end{array}$ \\
\hline Post-crisis & & $\begin{array}{c}0.010 * * * \\
(0.003)\end{array}$ & & $\begin{array}{c}0.009 * * * \\
(0.003)\end{array}$ & & $\begin{array}{c}0.009 * * * \\
(0.003)\end{array}$ & & $\begin{array}{c}0.008 * * \\
(0.004)\end{array}$ \\
\hline Year dummies & Yes & No & Yes & No & Yes & No & Yes & No \\
\hline Industry dummies & Yes & Yes & Yes & Yes & Yes & Yes & Yes & Yes \\
\hline$N$ & 338 & 338 & 334 & 334 & 298 & 298 & 295 & 295 \\
\hline$R$-squared & 0.328 & 0.243 & 0.349 & 0.282 & 0.345 & 0.253 & 0.376 & 0.313 \\
\hline $\begin{array}{l}\text { Notes: This table p } \\
\text { used in Models (1) } \\
\text { used in Models (5) } \\
\text { parentheses. } *, * *\end{array}$ & $\begin{array}{l}\text { s the rest } \\
\text { includes } \\
\text { include } \\
* \text { denote }\end{array}$ & $\begin{array}{l}\text { f probit } \\
\text { Class } 1 \\
\text { Class } \\
\text { istical si }\end{array}$ & $\begin{array}{l}\text { essions } \\
\text { lisition } \\
\text { uisition } \\
\text { cance ? }\end{array}$ & $\begin{array}{l}\text { Dissent } \\
\text { jerse tak } \\
\text { Targinal } \\
\%, 5 \% \text { ar }\end{array}$ & $\begin{array}{l}\text { M\&As a } \\
\text { ars and } \mathrm{r} \\
\text { ts are re } \\
\% \text {, respe }\end{array}$ & $\begin{array}{l}\text { e depend } \\
\text { ed-party } \\
\text { ted. Rob } \\
\text { ely. }\end{array}$ & $\begin{array}{l}\text { Jariable } \\
\text { actions } \\
\text { tandard }\end{array}$ & $\begin{array}{l}\text { e sample } \\
\text { e sample } \\
\text { ors are in }\end{array}$ \\
\hline
\end{tabular}

Table 5. Excess CEO compensation by dissent on M\&A proposals

\begin{tabular}{lcccc}
\hline & \multicolumn{2}{c}{ Median } & \multicolumn{2}{c}{ Mean } \\
\hline Dissent & High $(\mathrm{n}=178)$ & Low $(\mathrm{n}=178)$ & High $(\mathrm{n}=52)$ & Low $(\mathrm{n}=304)$ \\
\hline Excess Total Comp & 20.316 & -20.551 & 103.074 & -17.294 \\
Excess Cash Comp & 15.441 & -15.620 & 70.274 & -11.791 \\
\hline
\end{tabular}

Notes: This table shows the average excess CEO compensation by the level of dissent on M\&A proposals. Total compensation is the log of the sum of cash compensation and equity-linked compensation measured in $£ 000$ s at the fiscal year end prior to the announcement of M\&As. Cash compensation includes base salary, bonus, pension and other payments (e.g. benefits). Excess compensation is calculated as in Core, Guay, and Larcker (2008) and Feito-Ruiz and Renneboog (2017). Differences in means in both panels are tested by a two-tailed t-test. *,** and $* * *$ denote statistical significance at $10 \%, 5 \%$ and $1 \%$, respectively. 
Table 6. Determinants of dissent on M\&A resolutions: The impact of excess compensation and dissent on DRRs

\begin{tabular}{|c|c|c|c|c|c|c|c|c|}
\hline & (1) & (2) & (3) & (4) & (5) & (6) & (7) & (8) \\
\hline Excess Total Comp & $\begin{array}{c}0.003^{* *} \\
(0.001)\end{array}$ & $\begin{array}{c}0.003^{* *} \\
(0.001)\end{array}$ & $\begin{array}{c}0.003^{* *} \\
(0.001)\end{array}$ & $\begin{array}{l}0.003^{*} \\
(0.001)\end{array}$ & & & & \\
\hline DissentDRR & & & & & $\begin{array}{c}0.045^{* *} \\
(0.019)\end{array}$ & $\begin{array}{c}0.024 \\
(0.020)\end{array}$ & $\begin{array}{c}0.042 * * * \\
(0.016)\end{array}$ & $\begin{array}{c}0.024 \\
(0.019)\end{array}$ \\
\hline$C A R(-1 ; 1)$ & $\begin{array}{c}-0.040 * * * \\
(0.015)\end{array}$ & $\begin{array}{c}-0.031 * * \\
(0.015)\end{array}$ & $\begin{array}{c}-0.039 * * \\
(0.016)\end{array}$ & $\begin{array}{c}-0.032 * * \\
(0.016)\end{array}$ & $\begin{array}{l}-0.030 \\
(0.024)\end{array}$ & $\begin{array}{l}-0.030 \\
(0.024)\end{array}$ & $\begin{array}{l}-0.025 \\
(0.023)\end{array}$ & $\begin{array}{l}-0.024 \\
(0.023)\end{array}$ \\
\hline Firm Size & $\begin{array}{c}0.002 * * * \\
(0.001)\end{array}$ & $\begin{array}{c}0.002 * * \\
(0.001)\end{array}$ & $\begin{array}{c}0.002 * * \\
(0.001)\end{array}$ & $\begin{array}{c}0.002 * * \\
(0.001)\end{array}$ & $\begin{array}{c}0.004 * * * \\
(0.001)\end{array}$ & $\begin{array}{c}0.004 * * * \\
(0.001)\end{array}$ & $\begin{array}{c}0.004 * * * \\
(0.001)\end{array}$ & $\begin{array}{c}0.004 * * * \\
(0.001)\end{array}$ \\
\hline Diversifying & $\begin{array}{c}0.005^{* *} \\
(0.002)\end{array}$ & $\begin{array}{l}0.005^{*} \\
(0.003)\end{array}$ & $\begin{array}{c}0.005 * * \\
(0.002)\end{array}$ & $\begin{array}{c}0.005^{* *} * \\
(0.002)\end{array}$ & $\begin{array}{c}0.009 * * * \\
(0.003)\end{array}$ & $\begin{array}{c}0.009 * * * \\
(0.003)\end{array}$ & $\begin{array}{c}0.008 * * * \\
(0.003)\end{array}$ & $\begin{array}{c}0.009 * * * \\
(0.003)\end{array}$ \\
\hline Cash-payment & $\begin{array}{c}-0.004 * \\
(0.002)\end{array}$ & $\begin{array}{c}-0.005^{*} \\
(0.003)\end{array}$ & $\begin{array}{c}-0.004 * \\
(0.002)\end{array}$ & $\begin{array}{c}-0.005^{*} \\
(0.003)\end{array}$ & $\begin{array}{c}-0.007 * * \\
(0.003)\end{array}$ & $\begin{array}{c}-0.007 * * \\
(0.003)\end{array}$ & $\begin{array}{c}-0.006 * * \\
(0.003)\end{array}$ & $\begin{array}{c}-0.006 * * \\
(0.003)\end{array}$ \\
\hline BoardOwn & $\begin{array}{l}-0.000 \\
(0.000)\end{array}$ & $\begin{array}{l}-0.000 \\
(0.000)\end{array}$ & $\begin{array}{l}-0.000 \\
(0.000)\end{array}$ & $\begin{array}{l}-0.000 \\
(0.000)\end{array}$ & $\begin{array}{l}-0.000 \\
(0.000)\end{array}$ & $\begin{array}{l}-0.000 \\
(0.000)\end{array}$ & $\begin{array}{l}-0.000 \\
(0.000)\end{array}$ & $\begin{array}{l}-0.000 \\
(0.000)\end{array}$ \\
\hline OwnConc & $\begin{array}{c}0.000 \\
(0.000)\end{array}$ & $\begin{array}{c}0.000 \\
(0.000)\end{array}$ & $\begin{array}{c}0.000 \\
(0.000)\end{array}$ & $\begin{array}{l}-0.000 \\
(0.000)\end{array}$ & $\begin{array}{c}0.000 \\
(0.000)\end{array}$ & $\begin{array}{l}-0.000 \\
(0.000)\end{array}$ & $\begin{array}{c}0.000 \\
(0.000)\end{array}$ & $\begin{array}{l}-0.000 \\
(0.000)\end{array}$ \\
\hline Board Size & $\begin{array}{c}0.013 * * * \\
(0.005)\end{array}$ & $\begin{array}{c}0.013 * * * \\
(0.005)\end{array}$ & $\begin{array}{c}0.014 * * * \\
(0.005)\end{array}$ & $\begin{array}{c}0.014 * * * \\
(0.005)\end{array}$ & $\begin{array}{c}0.009 \\
(0.006)\end{array}$ & $\begin{array}{c}0.008 \\
(0.006)\end{array}$ & $\begin{array}{c}0.009 \\
(0.007)\end{array}$ & $\begin{array}{c}0.009 \\
(0.007)\end{array}$ \\
\hline Non-Exec & $\begin{array}{c}0.009 \\
(0.007)\end{array}$ & $\begin{array}{c}0.008 \\
(0.007)\end{array}$ & $\begin{array}{c}0.010 \\
(0.007)\end{array}$ & $\begin{array}{c}0.009 \\
(0.007)\end{array}$ & $\begin{array}{c}0.015 \\
(0.009)\end{array}$ & $\begin{array}{l}0.015^{*} \\
(0.008)\end{array}$ & $\begin{array}{c}0.011 \\
(0.009)\end{array}$ & $\begin{array}{c}0.012 \\
(0.008)\end{array}$ \\
\hline Gender & $\begin{array}{c}-0.005 * * * \\
(0.002)\end{array}$ & $\begin{array}{c}-0.005^{* * *} \\
(0.002)\end{array}$ & $\begin{array}{c}-0.005^{* * * *} \\
(0.002)\end{array}$ & $\begin{array}{c}-0.005 * * * \\
(0.002)\end{array}$ & $\begin{array}{c}-0.007 * * * \\
(0.002)\end{array}$ & $\begin{array}{c}-0.007 * * * \\
(0.002)\end{array}$ & $\begin{array}{c}-0.006 * * * \\
(0.002)\end{array}$ & $\begin{array}{c}-0.007 * * * \\
(0.002)\end{array}$ \\
\hline CEO Age & $\begin{array}{c}0.014 \\
(0.009)\end{array}$ & $\begin{array}{c}0.012 \\
(0.010)\end{array}$ & $\begin{array}{c}0.013 \\
(0.009)\end{array}$ & $\begin{array}{c}0.011 \\
(0.009)\end{array}$ & $\begin{array}{c}0.010 \\
(0.013)\end{array}$ & $\begin{array}{c}0.008 \\
(0.013)\end{array}$ & $\begin{array}{c}0.010 \\
(0.012)\end{array}$ & $\begin{array}{c}0.010 \\
(0.012)\end{array}$ \\
\hline$R O A$ & & & $\begin{array}{c}0.004 \\
(0.005)\end{array}$ & $\begin{array}{c}0.005 \\
(0.006)\end{array}$ & & & $\begin{array}{c}0.001 \\
(0.005)\end{array}$ & $\begin{array}{l}-0.001 \\
(0.005)\end{array}$ \\
\hline Tobin's $q$ & & & $\begin{array}{l}-0.001 \\
(0.001)\end{array}$ & $\begin{array}{c}-0.002 * \\
(0.001)\end{array}$ & & & $\begin{array}{l}-0.001 \\
(0.001)\end{array}$ & $\begin{array}{c}0.000 \\
(0.001)\end{array}$ \\
\hline Cash/TA & & & $\begin{array}{c}0.003 \\
(0.009)\end{array}$ & $\begin{array}{c}0.004 \\
(0.009)\end{array}$ & & & $\begin{array}{c}0.017 \\
(0.012)\end{array}$ & $\begin{array}{c}0.014 \\
(0.010)\end{array}$ \\
\hline Leverage & & & $\begin{array}{c}0.004 \\
(0.007)\end{array}$ & $\begin{array}{c}0.003 \\
(0.007)\end{array}$ & & & $\begin{array}{c}0.011 \\
(0.008)\end{array}$ & $\begin{array}{c}0.007 \\
(0.007)\end{array}$ \\
\hline Rel.Size & & & $\begin{array}{c}0.000 \\
(0.001)\end{array}$ & $\begin{array}{c}0.000 \\
(0.000)\end{array}$ & & & $\begin{array}{c}0.002 \\
(0.003)\end{array}$ & $\begin{array}{c}0.003 \\
(0.003)\end{array}$ \\
\hline Friendly & & & $\begin{array}{c}0.000 \\
(0.003)\end{array}$ & $\begin{array}{c}0.001 \\
(0.003)\end{array}$ & & & $\begin{array}{c}-0.006^{*} \\
(0.004)\end{array}$ & $\begin{array}{l}-0.005 \\
(0.004)\end{array}$ \\
\hline Cross-border & & & $\begin{array}{c}0.000 \\
(0.002)\end{array}$ & $\begin{array}{c}0.001 \\
(0.003)\end{array}$ & & & $\begin{array}{c}0.001 \\
(0.003)\end{array}$ & $\begin{array}{c}0.002 \\
(0.004)\end{array}$ \\
\hline Post-crisis & & $\begin{array}{c}0.010 * * * \\
(0.003)\end{array}$ & & $\begin{array}{c}0.009^{* * *} * \\
(0.003)\end{array}$ & & $\begin{array}{c}0.012 * * * \\
(0.004)\end{array}$ & & $\begin{array}{c}0.013 * * * \\
(0.004)\end{array}$ \\
\hline Year dummies & Yes & No & Yes & No & Yes & No & Yes & No \\
\hline Industry dummies & Yes & Yes & Yes & Yes & Yes & Yes & Yes & Yes \\
\hline$N$ & 338 & 338 & 334 & 334 & 192 & 192 & 190 & 190 \\
\hline$R$-squared & 0.358 & 0.268 & 0.380 & 0.310 & 0.621 & 0.547 & 0.683 & 0.589 \\
\hline
\end{tabular}


Table 7. M\&As announced following EGMs

\begin{tabular}{|c|c|c|c|c|}
\hline \multicolumn{5}{|c|}{ Panel A. Number of M\&As within one year after EGM } \\
\hline \multicolumn{2}{|c|}{ Number of M\&As } & \multicolumn{2}{|c|}{ Year 1 after EGM } & \\
\hline \multicolumn{2}{|c|}{1} & \multicolumn{2}{|c|}{170} & \\
\hline \multicolumn{2}{|l|}{2} & \multicolumn{2}{|c|}{83} & \\
\hline \multicolumn{2}{|l|}{3} & \multicolumn{2}{|c|}{37} & \\
\hline \multicolumn{2}{|l|}{4} & \multicolumn{2}{|c|}{21} & \\
\hline \multicolumn{2}{|l|}{5} & \multicolumn{2}{|c|}{12} & \\
\hline \multicolumn{2}{|l|}{6} & \multicolumn{2}{|c|}{7} & \\
\hline \multicolumn{2}{|l|}{7} & \multicolumn{2}{|c|}{4} & \\
\hline \multicolumn{2}{|l|}{8} & \multicolumn{2}{|c|}{3} & \\
\hline \multicolumn{2}{|l|}{9} & \multicolumn{2}{|c|}{3} & \\
\hline \multicolumn{2}{|l|}{10} & \multicolumn{2}{|c|}{1} & \\
\hline \multicolumn{2}{|c|}{ Overall } & \multicolumn{2}{|c|}{341} & \\
\hline \multicolumn{5}{|c|}{ Panel B. Market reaction to post-vote M\&A announcements } \\
\hline & \multicolumn{2}{|c|}{ Median } & \multicolumn{2}{|c|}{ Mean } \\
\hline Dissent & High & Low & High & Low \\
\hline$C A R(-1 ; 1)$ & 0.003 & $0.014 * *$ & -0.002 & $0.011 *$ \\
\hline$C A R(-2 ; 2)$ & 0.004 & $0.017 * *$ & 0.002 & 0.012 \\
\hline$C A R(-3 ; 3)$ & 0.003 & $0.019 * *$ & -0.001 & $0.013 *$ \\
\hline \multicolumn{5}{|c|}{$\begin{array}{l}\text { Notes: This table presents statistics of subsequent M\&As following voting on M\&A } \\
\text { resolutions. Panel A shows the number of M\&A deals announced in one year after the } \\
\text { voting. Panel B compares the average market reactions to the subsequent M\&A deals } \\
\text { of low and highly dissented acquirers. }{ }^{*}, * * \text { and } * * * \text { denote statistical significance of } \\
10 \%, 5 \% \text { and } 1 \% \text {, respectively. }\end{array}$} \\
\hline
\end{tabular}


Table 8. Impact of shareholder dissent on market perceptions of subsequent M\&A deals

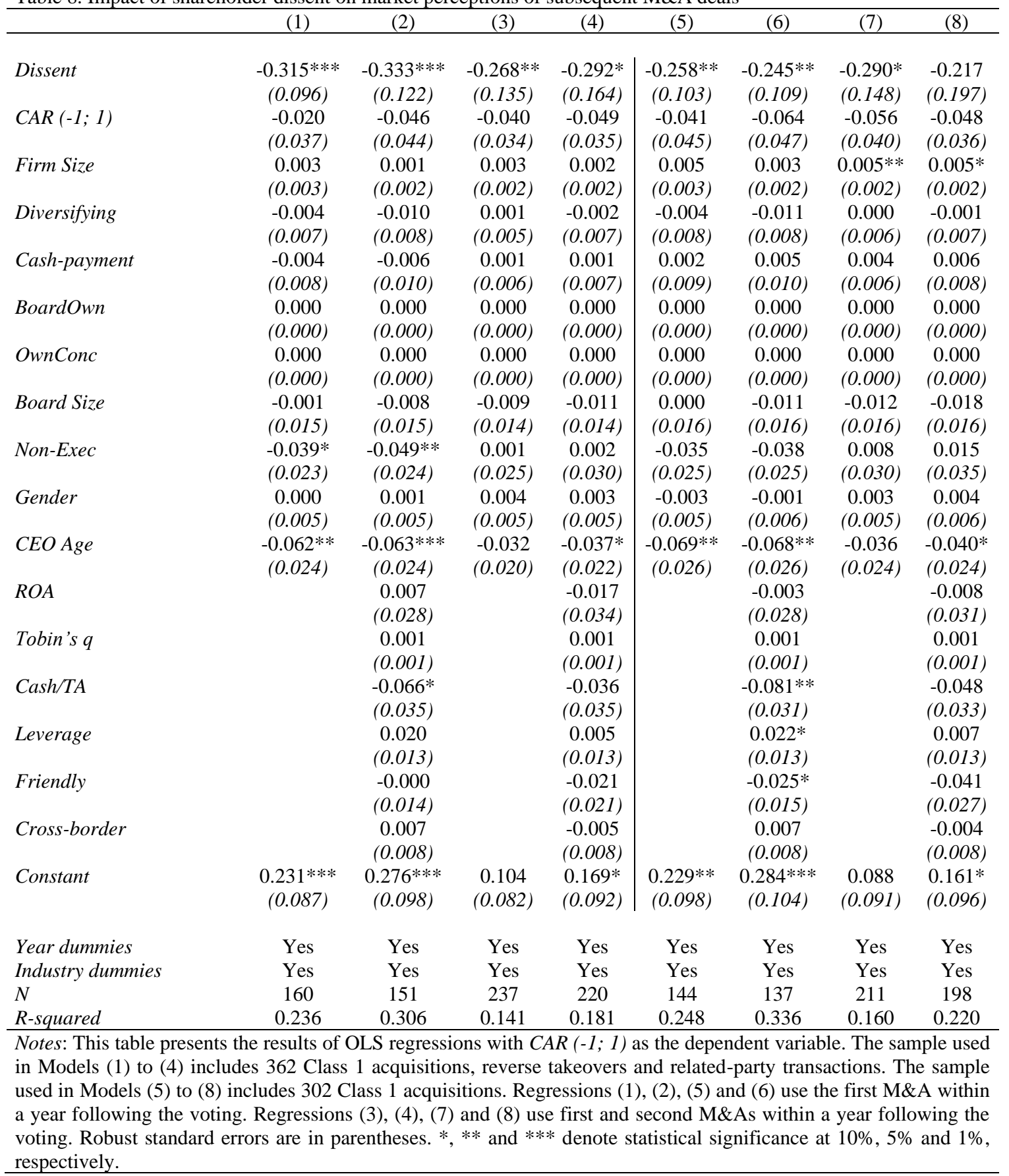


Table 9. Determinants of dissent on M\&A resolutions: Alternative measures of Dissent

\begin{tabular}{|c|c|c|c|c|c|c|c|c|}
\hline & $(1)$ & $(2)$ & (3) & (4) & (5) & (6) & $(7)$ & $(8)$ \\
\hline $\operatorname{CAR}(-1 ; 1)$ & $\begin{array}{c}-0.021 * * \\
(0.009)\end{array}$ & $\begin{array}{c}-0.017 * \\
(0.009)\end{array}$ & $\begin{array}{c}-0.853 * * * \\
(0.223)\end{array}$ & $\begin{array}{c}-0.742 * * * \\
(0.226)\end{array}$ & $\begin{array}{c}-0.019 * * \\
(0.009)\end{array}$ & $\begin{array}{l}-0.017^{*} \\
(0.009)\end{array}$ & $\begin{array}{c}-0.957 * * * \\
(0.251)\end{array}$ & $\begin{array}{c}-0.825 * * * \\
(0.213)\end{array}$ \\
\hline Firm Size & $\begin{array}{c}0.001 * * \\
(0.000)\end{array}$ & $\begin{array}{c}0.001 * * \\
(0.000)\end{array}$ & $\begin{array}{c}0.033 * * \\
(0.015)\end{array}$ & $\begin{array}{l}0.030 * \\
(0.015)\end{array}$ & $\begin{array}{c}0.001 \\
(0.000)\end{array}$ & $\begin{array}{l}0.001 * \\
(0.000)\end{array}$ & $\begin{array}{c}0.015 \\
(0.015)\end{array}$ & $\begin{array}{c}0.017 \\
(0.015)\end{array}$ \\
\hline Diversifying & $\begin{array}{c}0.003 * * \\
(0.001)\end{array}$ & $\begin{array}{l}0.003 * \\
(0.001)\end{array}$ & $\begin{array}{c}0.056 \\
(0.035)\end{array}$ & $\begin{array}{c}0.048 \\
(0.036)\end{array}$ & $\begin{array}{c}0.003 * * \\
(0.001)\end{array}$ & $\begin{array}{c}0.003 * * \\
(0.001)\end{array}$ & $\begin{array}{c}0.042 \\
(0.040)\end{array}$ & $\begin{array}{c}0.037 \\
(0.038)\end{array}$ \\
\hline Cash-payment & $\begin{array}{c}-0.003^{*} \\
(0.002)\end{array}$ & $\begin{array}{c}-0.003 * * \\
(0.002)\end{array}$ & $\begin{array}{l}-0.054 * \\
(0.032)\end{array}$ & $\begin{array}{c}-0.065^{*} \\
(0.036)\end{array}$ & $\begin{array}{l}-0.003^{*} \\
(0.002)\end{array}$ & $\begin{array}{c}-0.004 * * \\
(0.002)\end{array}$ & $\begin{array}{c}-0.073^{*} \\
(0.037)\end{array}$ & $\begin{array}{c}-0.078^{* *} \\
(0.037)\end{array}$ \\
\hline BoardOwn & $\begin{array}{l}-0.000^{*} \\
(0.000)\end{array}$ & $\begin{array}{l}-0.000 \\
(0.000)\end{array}$ & $\begin{array}{l}-0.002 \\
(0.002)\end{array}$ & $\begin{array}{l}-0.002 \\
(0.002)\end{array}$ & $\begin{array}{l}-0.000 \\
(0.000)\end{array}$ & $\begin{array}{l}-0.000 \\
(0.000)\end{array}$ & $\begin{array}{l}-0.006^{*} \\
(0.004)\end{array}$ & $\begin{array}{l}-0.007 \\
(0.005)\end{array}$ \\
\hline OwnConc & $\begin{array}{l}-0.000 \\
(0.000)\end{array}$ & $\begin{array}{l}-0.000 \\
(0.000)\end{array}$ & $\begin{array}{c}0.000 \\
(0.001)\end{array}$ & $\begin{array}{l}-0.000 \\
(0.002)\end{array}$ & $\begin{array}{l}-0.000 \\
(0.000)\end{array}$ & $\begin{array}{l}-0.000 \\
(0.000)\end{array}$ & $\begin{array}{l}-0.004 * \\
(0.002)\end{array}$ & $\begin{array}{c}-0.004^{*} \\
(0.002)\end{array}$ \\
\hline Board Size & $\begin{array}{c}0.008 * * \\
(0.003)\end{array}$ & $\begin{array}{c}0.007 * * \\
(0.003)\end{array}$ & $\begin{array}{c}0.232 * * * \\
(0.086)\end{array}$ & $\begin{array}{c}0.220 * * * \\
(0.085)\end{array}$ & $\begin{array}{c}0.008 * * \\
(0.003)\end{array}$ & $\begin{array}{l}0.006^{*} \\
(0.003)\end{array}$ & $\begin{array}{c}0.239 * * \\
(0.096)\end{array}$ & $\begin{array}{c}0.204 * * \\
(0.091)\end{array}$ \\
\hline Non-Exec & $\begin{array}{c}0.004 \\
(0.004)\end{array}$ & $\begin{array}{c}0.005 \\
(0.004)\end{array}$ & $\begin{array}{l}0.238 * \\
(0.128)\end{array}$ & $\begin{array}{l}0.238 * \\
(0.128)\end{array}$ & $\begin{array}{c}0.002 \\
(0.004)\end{array}$ & $\begin{array}{c}0.004 \\
(0.004)\end{array}$ & $\begin{array}{c}0.205 \\
(0.135)\end{array}$ & $\begin{array}{c}0.227 \\
(0.146)\end{array}$ \\
\hline Gender & $\begin{array}{c}-0.003 * * * \\
(0.001)\end{array}$ & $\begin{array}{c}-0.003 * * * \\
(0.001)\end{array}$ & $\begin{array}{c}-0.055^{* * *} \\
(0.026)\end{array}$ & $\begin{array}{l}-0.050^{*} \\
(0.027)\end{array}$ & $\begin{array}{c}-0.003 * * * * \\
(0.001)\end{array}$ & $\begin{array}{c}-0.002^{* *} * \\
(0.001)\end{array}$ & $\begin{array}{c}-0.062 * * \\
(0.032)\end{array}$ & $\begin{array}{c}-0.053^{*} \\
(0.028)\end{array}$ \\
\hline CEO Age & $\begin{array}{c}0.009 \\
(0.006)\end{array}$ & $\begin{array}{c}0.007 \\
(0.006)\end{array}$ & $\begin{array}{c}0.109 \\
(0.127)\end{array}$ & $\begin{array}{c}0.125 \\
(0.122)\end{array}$ & $\begin{array}{c}0.013^{* *} * \\
(0.006)\end{array}$ & $\begin{array}{c}0.012 * * \\
(0.006)\end{array}$ & $\begin{array}{c}0.407 * * * \\
(0.138)\end{array}$ & $\begin{array}{c}0.331 * * \\
(0.136)\end{array}$ \\
\hline$R O A$ & $\begin{array}{c}0.003 \\
(0.003)\end{array}$ & $\begin{array}{c}0.002 \\
(0.003)\end{array}$ & $\begin{array}{c}0.045 \\
(0.068)\end{array}$ & $\begin{array}{c}0.055 \\
(0.072)\end{array}$ & $\begin{array}{c}0.002 \\
(0.003)\end{array}$ & $\begin{array}{c}0.001 \\
(0.003)\end{array}$ & $\begin{array}{c}0.077 \\
(0.080)\end{array}$ & $\begin{array}{c}0.056 \\
(0.083)\end{array}$ \\
\hline Tobin's q & $\begin{array}{l}-0.001 \\
(0.001)\end{array}$ & $\begin{array}{l}-0.001 \\
(0.001)\end{array}$ & $\begin{array}{l}-0.008 \\
(0.008)\end{array}$ & $\begin{array}{l}-0.013 \\
(0.008)\end{array}$ & $\begin{array}{l}-0.000 \\
(0.000)\end{array}$ & $\begin{array}{l}-0.000 \\
(0.000)\end{array}$ & $\begin{array}{l}-0.011 \\
(0.007)\end{array}$ & $\begin{array}{l}-0.010 \\
(0.006)\end{array}$ \\
\hline Cash/TA & $\begin{array}{c}0.007 \\
(0.006)\end{array}$ & $\begin{array}{c}0.007 \\
(0.006)\end{array}$ & $\begin{array}{l}-0.025 \\
(0.135)\end{array}$ & $\begin{array}{l}-0.004 \\
(0.151)\end{array}$ & $\begin{array}{c}0.005 \\
(0.005)\end{array}$ & $\begin{array}{c}0.005 \\
(0.005)\end{array}$ & $\begin{array}{c}0.023 \\
(0.130)\end{array}$ & $\begin{array}{c}0.033 \\
(0.151)\end{array}$ \\
\hline Leverage & $\begin{array}{c}0.002 \\
(0.004)\end{array}$ & $\begin{array}{c}0.001 \\
(0.004)\end{array}$ & $\begin{array}{l}-0.048 \\
(0.092)\end{array}$ & $\begin{array}{l}-0.016 \\
(0.084)\end{array}$ & $\begin{array}{c}0.001 \\
(0.004)\end{array}$ & $\begin{array}{c}0.000 \\
(0.005)\end{array}$ & $\begin{array}{l}-0.067 \\
(0.098)\end{array}$ & $\begin{array}{l}-0.015 \\
(0.085)\end{array}$ \\
\hline Rel.Size & $\begin{array}{c}0.000 \\
(0.000)\end{array}$ & $\begin{array}{c}0.000 \\
(0.000)\end{array}$ & $\begin{array}{l}-0.005 \\
(0.025)\end{array}$ & $\begin{array}{l}-0.002 \\
(0.011)\end{array}$ & $\begin{array}{c}0.000 \\
(0.000)\end{array}$ & $\begin{array}{c}0.000 \\
(0.000)\end{array}$ & $\begin{array}{l}-0.023 \\
(0.034)\end{array}$ & $\begin{array}{l}-0.013 \\
(0.029)\end{array}$ \\
\hline Friendly & $\begin{array}{c}0.001 \\
(0.002)\end{array}$ & $\begin{array}{c}0.001 \\
(0.002)\end{array}$ & $\begin{array}{l}-0.068 \\
(0.051)\end{array}$ & $\begin{array}{l}-0.051 \\
(0.054)\end{array}$ & $\begin{array}{c}0.000 \\
(0.002)\end{array}$ & $\begin{array}{l}-0.000 \\
(0.002)\end{array}$ & $\begin{array}{c}0.045 \\
(0.058)\end{array}$ & $\begin{array}{c}0.014 \\
(0.057)\end{array}$ \\
\hline Cross-border & $\begin{array}{c}0.000 \\
(0.002)\end{array}$ & $\begin{array}{c}0.001 \\
(0.002)\end{array}$ & $\begin{array}{c}0.010 \\
(0.040)\end{array}$ & $\begin{array}{c}0.021 \\
(0.041)\end{array}$ & $\begin{array}{c}0.001 \\
(0.002)\end{array}$ & $\begin{array}{c}0.002 \\
(0.002)\end{array}$ & $\begin{array}{c}0.039 \\
(0.043)\end{array}$ & $\begin{array}{c}0.059 \\
(0.042)\end{array}$ \\
\hline Post-crisis & & $\begin{array}{c}0.006^{* *} \\
(0.002)\end{array}$ & & $\begin{array}{c}0.063 \\
(0.045)\end{array}$ & & $\begin{array}{c}0.006 * * \\
(0.003)\end{array}$ & & $\begin{array}{c}0.059 \\
(0.048)\end{array}$ \\
\hline Year dummies & Yes & No & Yes & No & Yes & No & Yes & No \\
\hline Industry dummies & Yes & Yes & Yes & Yes & Yes & Yes & Yes & Yes \\
\hline$N$ & 329 & 329 & 334 & 334 & 290 & 290 & 295 & 295 \\
\hline$R$-squared & 0.346 & 0.277 & 0.341 & 0.283 & 0.414 & 0.339 & 0.387 & 0.341 \\
\hline $\begin{array}{l}\text { Notes: This table } \mathrm{p} \\
\text { dependent variable } \\
\text { total number of vot } \\
\text { equal to } 1 \text { when di } \\
\text { Class } 1 \text { acquisition } \\
\text { Class } 1 \text { acquisition } \\
\text { statistical significan }\end{array}$ & $\begin{array}{l}\text { sents the re } \\
(1),(2),(5) \\
\text { that can be } \\
\text { ent is higher } \\
\text { reverse takec } \\
\text { Marginal e }\end{array}$ & $\begin{array}{l}\text { ults of pro } \\
\text { and (6) is } \\
\text { cast. The d } \\
\text { than mean } \\
\text { vers and re } \\
\text { fects are r }\end{array}$ & $\begin{array}{l}\text { it regressic } \\
\text { issent } 2 \text { me } \\
\text { oendent val } \\
\text { Dissent, } 0 \\
\text { ated-party t } \\
\text { ported. Rob }\end{array}$ & $\begin{array}{l}\text { with two } \\
\text { red as the } \\
\text { le in (3), } \\
\text { rwise. Th } \\
\text { sactions. } \\
\text { standard }\end{array}$ & $\begin{array}{l}\text { rnatives } \\
\text { mber of } \\
\text { (7) and } \\
\text { ample us } \\
\text { sample } \\
\text { ors are i }\end{array}$ & $\begin{array}{l}\text { asures } \\
\text { s 'agail } \\
\text { s a dum } \\
\text { n Mode } \\
\text { in Moc } \\
\text { renthes }\end{array}$ & $\begin{array}{l}\text { lissent or } \\
\text { as a per } \\
\text { variable } \\
\text { (1) to }(4) \\
\text { (5) to }(8 \\
*, * * \text { an }\end{array}$ & $\begin{array}{l}\text { \&As. The } \\
\text { age of the } \\
\text { g Dissent } \\
\text { ludes } 362 \\
\text { ludes } 302 \\
\text { ** denote }\end{array}$ \\
\hline
\end{tabular}


Table 10. Determinants of dissent on M\&As: Alternative measures of shareholder dissatisfaction with management

\begin{tabular}{|c|c|c|c|c|c|c|c|c|}
\hline & $(1)$ & (2) & (3) & (4) & (5) & (6) & (7) & $(8)$ \\
\hline Excess Cash Comp & $\begin{array}{l}0.002^{*} \\
(0.001)\end{array}$ & $\begin{array}{l}0.003^{*} \\
(0.002)\end{array}$ & $\begin{array}{l}0.003 * \\
(0.001)\end{array}$ & $\begin{array}{c}0.003 \\
(0.002)\end{array}$ & & & & \\
\hline Resid.DRR & & & & & $\begin{array}{c}0.041 * * \\
(0.018)\end{array}$ & $\begin{array}{c}0.032 \\
(0.021)\end{array}$ & $\begin{array}{c}0.039 * * \\
(0.015)\end{array}$ & $\begin{array}{c}0.032 \\
(0.019)\end{array}$ \\
\hline$C A R(-1 ; 1)$ & $\begin{array}{c}-0.040 * * \\
(0.016)\end{array}$ & $\begin{array}{c}-0.031 * * \\
(0.015)\end{array}$ & $\begin{array}{c}-0.040 * * \\
(0.016)\end{array}$ & $\begin{array}{c}-0.032 * * \\
(0.016)\end{array}$ & $\begin{array}{l}-0.029 \\
(0.022)\end{array}$ & $\begin{array}{l}-0.030 \\
(0.022)\end{array}$ & $\begin{array}{l}-0.023 \\
(0.022)\end{array}$ & $\begin{array}{l}-0.024 \\
(0.022)\end{array}$ \\
\hline Firm Size & $\begin{array}{c}0.002 * * * \\
(0.001)\end{array}$ & $\begin{array}{c}0.002 * * * \\
(0.001)\end{array}$ & $\begin{array}{c}0.002 * * \\
(0.001)\end{array}$ & $\begin{array}{c}0.002 * * \\
(0.001)\end{array}$ & $\begin{array}{c}0.004 * * * \\
(0.001)\end{array}$ & $\begin{array}{c}0.004 * * * \\
(0.001)\end{array}$ & $\begin{array}{c}0.004 * * * \\
(0.001)\end{array}$ & $\begin{array}{c}0.004 * * * \\
(0.001)\end{array}$ \\
\hline Diversifying & $\begin{array}{l}0.005^{*} \\
(0.002)\end{array}$ & $\begin{array}{l}0.005^{*} \\
(0.003)\end{array}$ & $\begin{array}{c}0.004 * * \\
(0.002)\end{array}$ & $\begin{array}{c}0.004 * * \\
(0.002)\end{array}$ & $\begin{array}{c}0.008 * * \\
(0.003)\end{array}$ & $\begin{array}{c}0.008 * * * \\
(0.003)\end{array}$ & $\begin{array}{c}0.008 * * * \\
(0.003)\end{array}$ & $\begin{array}{c}0.008 * * * \\
(0.003)\end{array}$ \\
\hline Cash-payment & $\begin{array}{l}-0.004 * \\
(0.002)\end{array}$ & $\begin{array}{c}-0.005^{*} \\
(0.003)\end{array}$ & $\begin{array}{r}-0.004 * \\
(0.002)\end{array}$ & $\begin{array}{c}-0.005^{*} \\
(0.003)\end{array}$ & $\begin{array}{c}-0.005^{*} \\
(0.003)\end{array}$ & $\begin{array}{c}-0.006 * * \\
(0.003)\end{array}$ & $\begin{array}{l}-0.004 \\
(0.002)\end{array}$ & $\begin{array}{c}-0.005^{*} \\
(0.003)\end{array}$ \\
\hline BoardOwn & $\begin{array}{l}-0.000 \\
(0.000)\end{array}$ & $\begin{array}{l}-0.000 \\
(0.000)\end{array}$ & $\begin{array}{l}-0.000 \\
(0.000)\end{array}$ & $\begin{array}{l}-0.000 \\
(0.000)\end{array}$ & $\begin{array}{l}-0.000 \\
(0.000)\end{array}$ & $\begin{array}{l}-0.000 \\
(0.000)\end{array}$ & $\begin{array}{l}-0.000 \\
(0.000)\end{array}$ & $\begin{array}{l}-0.000 \\
(0.000)\end{array}$ \\
\hline OwnConc & $\begin{array}{c}0.000 \\
(0.000)\end{array}$ & $\begin{array}{c}0.000 \\
(0.000)\end{array}$ & $\begin{array}{c}0.000 \\
(0.000)\end{array}$ & $\begin{array}{l}-0.000 \\
(0.000)\end{array}$ & $\begin{array}{c}0.000 \\
(0.000)\end{array}$ & $\begin{array}{l}-0.000 \\
(0.000)\end{array}$ & $\begin{array}{l}-0.000 \\
(0.000)\end{array}$ & $\begin{array}{l}-0.000 \\
(0.000)\end{array}$ \\
\hline Board Size & $\begin{array}{c}0.013 * * * \\
(0.005)\end{array}$ & $\begin{array}{c}0.013 * * \\
(0.005)\end{array}$ & $\begin{array}{c}0.014 * * * \\
(0.005)\end{array}$ & $\begin{array}{c}0.014 * * * \\
(0.005)\end{array}$ & $\begin{array}{c}0.007 \\
(0.006)\end{array}$ & $\begin{array}{c}0.007 \\
(0.006)\end{array}$ & $\begin{array}{c}0.009 \\
(0.007)\end{array}$ & $\begin{array}{c}0.009 \\
(0.006)\end{array}$ \\
\hline Non-Exec & $\begin{array}{c}0.009 \\
(0.006)\end{array}$ & $\begin{array}{c}0.008 \\
(0.007)\end{array}$ & $\begin{array}{c}0.010 \\
(0.007)\end{array}$ & $\begin{array}{c}0.009 \\
(0.007)\end{array}$ & $\begin{array}{l}0.015^{*} \\
(0.009)\end{array}$ & $\begin{array}{l}0.015^{*} \\
(0.009)\end{array}$ & $\begin{array}{c}0.012 \\
(0.009)\end{array}$ & $\begin{array}{c}0.012 \\
(0.008)\end{array}$ \\
\hline Gender & $\begin{array}{c}- \\
0.005 * * * \\
(0.002)\end{array}$ & $\begin{array}{c}- \\
0.005^{* * *} \\
(0.002)\end{array}$ & $\begin{array}{c}- \\
0.005^{* * *} \\
(0.002)\end{array}$ & $\begin{array}{c}- \\
0.005^{* * *} \\
(0.002)\end{array}$ & $\begin{array}{c}- \\
0.006 * * * \\
(0.002)\end{array}$ & $\begin{array}{c}- \\
0.006 * * * \\
(0.002)\end{array}$ & $\begin{array}{c}- \\
0.005^{* * *} \\
(0.002)\end{array}$ & $\begin{array}{c}- \\
0.006^{* * *} \\
(0.002)\end{array}$ \\
\hline CEO Age & $\begin{array}{c}0.014 \\
(0.009)\end{array}$ & $\begin{array}{c}0.013 \\
(0.010)\end{array}$ & $\begin{array}{c}0.013 \\
(0.009)\end{array}$ & $\begin{array}{c}0.012 \\
(0.010)\end{array}$ & $\begin{array}{c}0.011 \\
(0.012)\end{array}$ & $\begin{array}{c}0.008 \\
(0.012)\end{array}$ & $\begin{array}{c}0.011 \\
(0.012)\end{array}$ & $\begin{array}{c}0.009 \\
(0.011)\end{array}$ \\
\hline$R O A$ & & & $\begin{array}{c}0.005 \\
(0.005)\end{array}$ & $\begin{array}{c}0.005 \\
(0.006)\end{array}$ & & & $\begin{array}{c}0.001 \\
(0.005)\end{array}$ & $\begin{array}{l}-0.001 \\
(0.005)\end{array}$ \\
\hline Tobin's $q$ & & & $\begin{array}{l}-0.001 \\
(0.001)\end{array}$ & $\begin{array}{l}-0.002^{*} \\
(0.001)\end{array}$ & & & $\begin{array}{l}-0.001 \\
(0.001)\end{array}$ & $\begin{array}{l}-0.000 \\
(0.001)\end{array}$ \\
\hline Cash/TA & & & $\begin{array}{c}0.004 \\
(0.009)\end{array}$ & $\begin{array}{c}0.006 \\
(0.009)\end{array}$ & & & $\begin{array}{c}0.021 * * \\
(0.010)\end{array}$ & $\begin{array}{c}0.015 \\
(0.010)\end{array}$ \\
\hline Leverage & & & $\begin{array}{c}0.004 \\
(0.007)\end{array}$ & $\begin{array}{c}0.004 \\
(0.007)\end{array}$ & & & $\begin{array}{c}0.012 \\
(0.008)\end{array}$ & $\begin{array}{c}0.007 \\
(0.007)\end{array}$ \\
\hline Rel.Size & & & $\begin{array}{c}0.000 \\
(0.001)\end{array}$ & $\begin{array}{c}0.000 \\
(0.000)\end{array}$ & & & $\begin{array}{c}0.001 \\
(0.003)\end{array}$ & $\begin{array}{c}0.003 \\
(0.003)\end{array}$ \\
\hline Friendly & & & $\begin{array}{c}0.001 \\
(0.003)\end{array}$ & $\begin{array}{c}0.002 \\
(0.003)\end{array}$ & & & $\begin{array}{c}-0.007^{*} \\
(0.004)\end{array}$ & $\begin{array}{c}-0.006^{*} \\
(0.003)\end{array}$ \\
\hline Cross-border & & & $\begin{array}{c}0.000 \\
(0.002)\end{array}$ & $\begin{array}{c}0.001 \\
(0.003)\end{array}$ & & & $\begin{array}{c}0.001 \\
(0.003)\end{array}$ & $\begin{array}{c}0.002 \\
(0.004)\end{array}$ \\
\hline Post-crisis & & $\begin{array}{c}0.010 * * * \\
(0.003)\end{array}$ & & $\begin{array}{c}0.009 * * * \\
(0.003)\end{array}$ & & $\begin{array}{c}0.011 * * * \\
(0.004)\end{array}$ & & $\begin{array}{c}0.012 * * * * \\
(0.004)\end{array}$ \\
\hline Year dummies & Yes & No & Yes & No & Yes & No & Yes & No \\
\hline Industry dummies & Yes & Yes & Yes & Yes & Yes & Yes & Yes & Yes \\
\hline$N$ & 338 & 338 & 334 & 334 & 187 & 187 & 185 & 185 \\
\hline$R$-squared & 0.357 & 0.276 & 0.380 & 0.319 & 0.592 & 0.522 & 0.680 & 0.577 \\
\hline
\end{tabular}


Table 11. Impact of shareholder dissent on market perceptions of subsequent M\&A deals: Two stage regression

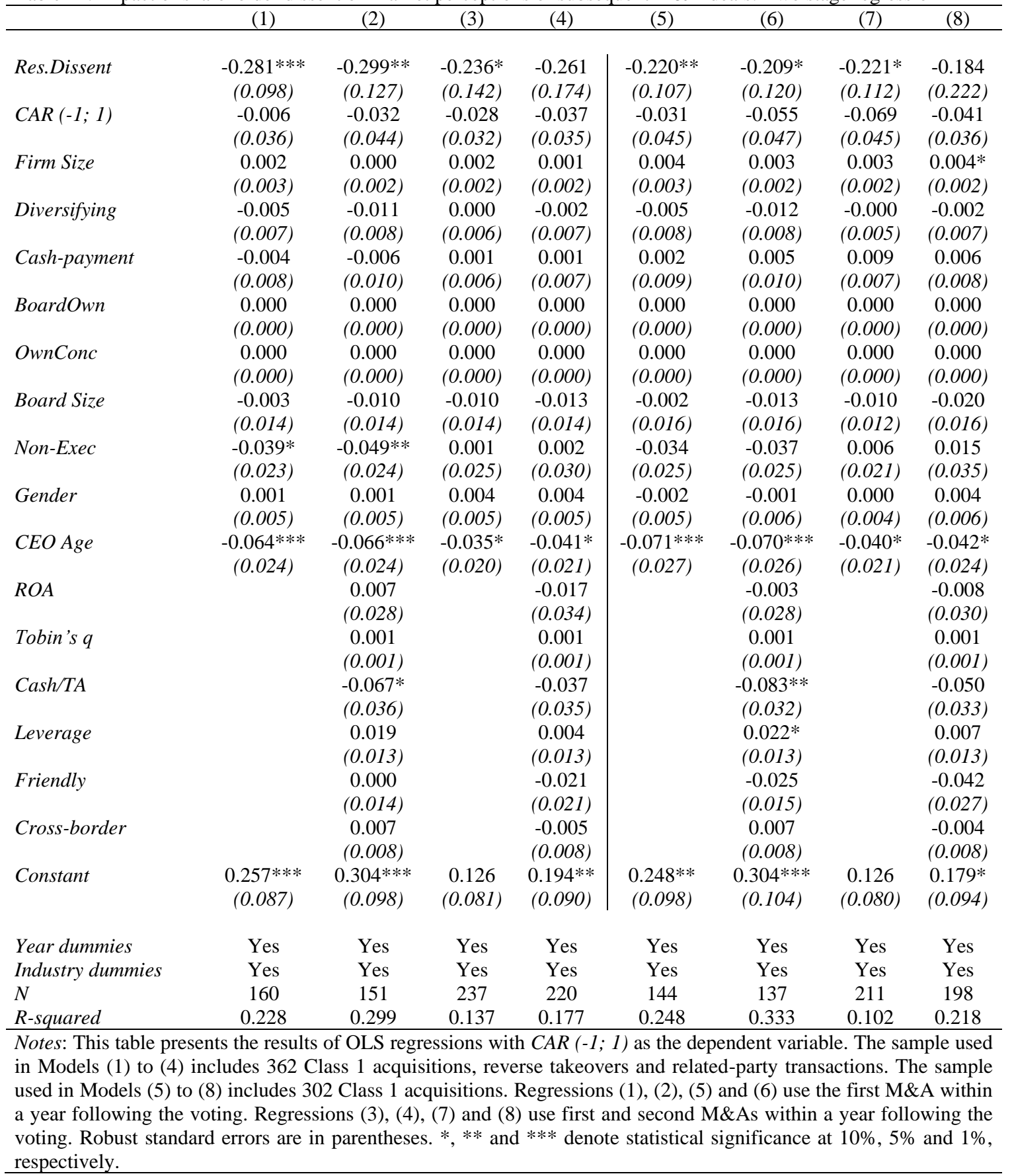




\section{References}

AIM. 2016. AIM Rules for Companies. London: London Stock Exchange.

Alexandridis, G., C.F. Mavrovitis, and N.G. Travlos. 2012. "How have M\&As Changed? Evidence from the Sixth Merger Wave.” European Journal of Finance 18 (8): 663-688.

Ataullah, A., I. Davidson, H. Le, and G. Wood. 2014. "Corporate Diversification, Information Asymmetry and Insider Trading." British Journal of Management 25 (2): 228-251.

Australian Stock Exchange. 2015. "Reverse Takeovers: Consultation on Shareholder Approval Requirements for Listed Company Mergers." Australian Stock Exchange. Accessed 20 January 2017. http://www.asx.com.au/documents/public-consultations/reverse_takeovers_nov15.pdf

Baumol, W.J. 1959. Business Behaviour, Value and Growth. London: Macmillan.

Bebchuk, L.A. 2005. “The Case for Increasing Shareholder Power.” Harvard Law Review 118 (3): 833-914.

Bebchuk, L.A., and J. Fried. 2003. "Executive Compensation as an Agency Problem.” Journal of Economic Perspectives 17 (3): 71-92.

Bebchuk, L.A., and J. Fried. 2006. "Pay without Performance: Overview of the Issues." Academy of Management Perspectives 20 (1): 5-24.

Becht, M., A. Polo, and S. Rossi. 2016. “Does Mandatory Shareholder Voting Prevent Bad Acquisitions?” Review of Financial Studies 29 (11): 3035-3067.

Berger, P.G., and E. Ofek. 1995. “Diversification's Effect on Firm Value.” Journal of Financial Economics 37 (1): 39-65.

Berle, A.A., and G.C. Means. 1932. The Modern Corporation and Private Property. New York: Harcourt Brace.

Bethel, J.E., and S.L. Gillan. 2002. "The Impact of the Institutional and Regulatory Environment on Shareholder Voting." Financial Management 31 (4): 29-54.

Betzer, A., M. Doumet, and M. Goergen. 2015. "Disentangling the Link between Stock and Accounting Performance in Acquisitions.” European Journal of Finance 21 (9): 755-771.

Burch, T.R., A.G. Morgan, and J.G. Wolf. 2004. "Is Acquiring-Firm Shareholder Approval in Stock-for-Stock Mergers Perfunctory?" Financial Management 33 (4): 45-69.

Cai, J., J.L. Garner, and R.A. Walkling. 2009. “Electing Directors.” Journal of Finance 64 (5): 2389-2421.

Conyon, M., and G. Sadler. 2010. "Shareholder Voting and Directors' Remuneration Report Legislation: Say on Pay in the UK." Corporate Governance: An International Review 18 (4): 296-312.

Core, J.E., W. Guay, and D.F. Larcker. 2008. "The Power of the Pen and Executive Compensation.” Journal of Financial Economics 88 (1): 1-25.

Cuñat, V., M. Gine, and M. Guadalupe. 2012. "The Vote Is Cast: The Effect of Corporate Governance on Shareholder Value.” Journal of Finance 67 (5): 1943-1977.

Danbolt, J. 1995. “An Analysis of Gains and Losses to Shareholders of Foreign Bidding Companies Engaged in Cross-Border Acquisitions into the United Kingdom, 1986-1991.” European Journal of Finance 1 (3): 279-309.

Department of Trade and Industry. 2002. Statutory Instrument 2002 No. 1986: Directors' Remuneration Report Regulations. London: HMSO. 
Ertimur, Y., F. Ferri, and D. Oesch. 2018. “Understanding Uncontested Director Elections.” Management Science 64 (7): 3400-3420.

European Commission. 2014. "Proposal for a Directive of the European Parliament and of the Council Amending Directive 2007/36/EC.” EUR-Lex. Accessed 20 February 2017. http://eur-lex.europa.eu/legalcontent/EN/TXT/?uri=CELEX:52014PC0213

Fama, E.F., and M.C. Jensen. 1983. "Separation of Ownership and Control." Journal of Law and Economics 26 (2): 301-325.

Fahlenbrach, R. 2009. "Shareholder Rights, Boards, and CEO Compensation.” Review of Finance 13 (1): 81-113.

Feito-Ruiz, I., and L. Renneboog. 2017. “Takeovers and (Excess) CEO Compensation.” Journal of International Financial Markets, Institutions and Money 50: 156-181.

Ferri, F., and D.A. Maber. 2013. "Say on Pay Votes and CEO Compensation: Evidence from the UK." Review of Finance 17 (2): 527-563.

Fischer, P.E., J.D. Gramlich, B.P. Miller, and H.D. White. 2009. "Investor Perceptions of Board Performance: Evidence from Uncontested Director Elections." Journal of Accounting and Economics 48 (2-3): 172189.

FRC. 2010. UK Stewardship Code. London: Financial Reporting Council.

FRC. 2013. Developments in Corporate Governance 2013. London: Financial Reporting Council.

Financial Times. 2009. "RBS Investors Reject Remuneration Report.” Financial Times. Accessed 23 August 2017. https://www.ft.com/content/1837663e-201b-11de-a1df-00144feabdc0

Financial Times. 2017a. "Shareholders Ready to Show Their Hand Over Executive Pay." Financial Times. Accessed 23 August 2017. https://www.ft.com/content/5c031f44-13a5-11e7-80f4-13e067d5072c

Financial Times. 2017b. "Investors Back UK Government Attempt to Curb Executive Pay." Financial Times. Accessed 23 August 2017. https://www.ft.com/content/f8e9534e-f516-11e6-95ee-f14e55513608

Goergen, M., and L. Renneboog. 2001. "Strong Managers and Passive Institutional Investors in the UK." in Barca, F., and M. Becht. The Control of Corporate Europe, 259-284, Oxford University Press.

Gordon, L.A., and J. Pound. 1993. "Information, Ownership Structure, and Shareholder Voting: Evidence from Shareholder-Sponsored Corporate Governance Proposals.” Journal of Finance 48 (2): 697-718.

Graham, J.R., M.L. Lemmon, and J.G. Wolf. 2002. “Does Corporate Diversification Destroy Value?” Journal of Finance 57 (2): 695-720.

Gregory-Smith, I., and B.G.M. Main. 2014. "Binding Votes on Executive Remuneration.” Working Paper, University of Sheffield.

Gregory-Smith, I., S. Thompson, and P.W. Wright. 2014. "CEO Pay and Voting Dissent Before and After the Crisis." Economic Journal 124 (574): 22-39.

Grinblatt, M., and T. Sheridan. 2002. Financial Markets and Corporate Strategy 2nd edition. New York: McGraw Hill Irwin.

Grundfest, J.A. 1993. "Just Vote No: A Minimalist Strategy for Dealing with Barbarians inside the Gates." Stanford Law Review 45 (4): 857-937.

Harford, J., and K. Li. 2007. "Decoupling CEO Wealth and Firm Performance: The Case of Acquiring CEOs." Journal of Finance 62 (2): 917-949. 
Hietala, P., S.N. Kaplan, and D.T. Robinson. 2003. "What Is the Price of Hubris? Using Takeover Battles to Infer Overpayments and Synergies.” Financial Management 32 (3): 5-31.

Hillman, A. J., C. Shropshire, S.T. Certo, D.R. Dalton, and C.M. Dalton. 2011. "What I Like About You: A Multilevel Study of Shareholder Discontent with Director Monitoring." Organization Science 22 (3): 675-687.

Iliev, P., K.V. Lins, D.P. Miller, and L. Roth. 2015. "Shareholder Voting and Corporate Governance around the World.” Review of Financial Studies 28 (8): 2167-2202.

Jensen, M.C. 1986. “Agency Costs of Free Cash Flow, Corporate Finance, and Takeovers.” American Economic Review 76 (2): 323-329.

Jensen, M.C., and K.J. Murphy. 1990. "Performance Pay and Top-Management Incentives.” Journal of Political Economy 98 (2): 225-264.

LR. 2015. UK Listing Rules. London: Financial Conduct Authority.

Manifest. 2009. "Memorandum from Manifest Information Services Ltd." Accessed 10 December 2016. http://www.publications.parliament.uk/pa/cm200809/cmselect/cmtreasy/144/144w275.htm

Masulis, R.W., C. Wang, and F. Xie. 2007. “Corporate Governance and Acquirer Returns.” Journal of Finance 62 (4): 1851-1889.

McCahery, J.A., Z. Sautner, and L.T. Starks. 2016. "Behind the Scenes: The Corporate Governance Preferences of Institutional Investors.” Journal of Finance 71 (6): 2905-2932.

Mitchell, M., T. Pulvino, and E. Stafford. 2004. "Price Pressure around Mergers." Journal of Finance 59 (1): 31 63.

Moeller, S.B., F. Schlingemann, and R. Stulz. 2004. "Firm Size and the Gains from Acquisitions." Journal of Financial Economics 73 (2): 201-228.

Moeller, S.B., F. Schlingemann, and R. Stulz. 2005. "Wealth Destruction on a Massive Scale? A Study of Acquiring-Firm Returns in the Recent Merger Wave." Journal of Finance 60 (2): 757-782.

Morck, R., A. Shleifer, and R.W. Vishny. 1990. “Do Managerial Objectives Drive Bad Acquisitions?” Journal of Finance 45 (1): 31-48.

Murphy, K. 1999. "Executive Compensation." in Ashenfelter, O., and D. Card. Handbook of Labor Economics, 2485-2563. North Holland: Elsevier.

Ontario Securities Commission. 2009. "TSX Notice of Approval: Amendments to Part VI of the Toronto Stock Exchange ('TSX') Company Manual." Ontario Securities Commission. Accessed 14 March 2017. http://www.osc.gov.on.ca/en/Marketplaces_xrr-tse_20090925_na-amd-tsx-manual.htm

Papke, L.E., and J.M. Wooldridge. 1996. "Econometric Methods for Fractional Response Variables with an Application to 401(K) Plan Participation Rates.” Journal of Applied Econometrics 11 (6): 619-632.

Parrino, R., R.W. Sias, and L.T. Starks. 2003. "Voting with Their Feet: Institutional Ownership Changes around Forced CEO Turnover." Journal of Financial Economics 68: 3-46.

Roberts, J. 2014. "UK Shareholder Activism: A Toolbox for 2014.” Harvard Law School Forum. Accessed 24 February 2017. https://corpgov.law.harvard.edu/2014/03/02/uk-shareholder-activism-a-toolbox-for2014/

Roll, R. 1986. “The Hubris Hypothesis of Corporate Takeovers.” Journal of Business 59 (2): 197-216. 
Sauerwald, S., J.H. Van Oosterhout, and M. Van Essen. 2016. "Expressive Shareholder Democracy: A Multilevel Study of Shareholder Dissent in 15 Western European Countries." Journal of Management Studies 53 (4): 520-551.

Schult, L., and T. Nikoleyczik. 2012. "Shareholder Approval for Corporate Acquisitions - The Commerzbank/Dresdner Bank Case." Corporate and Law Newsletter. Accessed 20 February 2017. http://www.glns.de/fileadmin/user_upload/dokumente/IBA_M_A_Newsletter.pdf

Segain, H., and E. Favier. 2017. "Getting the Deal through - GTDT." Getting the Deal Through. Accessed 22 February 2017. https://gettingthedealthrough.com/intelligence/34/article/4573/mergers-acquisitionsfrance

Stathopoulos, K., and G. Voulgaris. 2016. "The Importance of Shareholder Activism: The Case of Say-on-Pay." Corporate Governance: An International Review 24 (3): 359-370.

The Guardian. 2009. "Xstrata's Glencore Rights Issue Angers Shareholders.” The Guardian. Accessed 26 August 2017. http://www.theguardian.com/business/2009/feb/18/xstrata-rights-issue-glencore

The Telegraph. 2011. "Capital Shopping Centres Seals £1.6bn Trafford Centre Deal Despite Simon Property Group's Concerns." The Telegraph. Accessed 26 August 2017. http://www.telegraph.co.uk/finance/newsbysector/constructionandproperty/8284524/Capital-ShoppingCentres-seals-1.6bn-Trafford-Centre-deal-despite-Simon-Property-Groups-concerns.html

Tirole, J. 2001. “Corporate Governance.” Econometrica 69 (1): 1-35.

Yermack, D. 2010. "Shareholder Voting and Corporate Governance." Annual Review of Financial Economics 2: 103-125. 


\section{Appendix A - UK Listing Rules}

In the UK Listing Rules (LR 2015) there are three cases where approval is mandatory:

First, when a deal is large relative to the acquirer (LR 10). The comparison of size is made by using percentage ratios resulting from applying class test calculations to an acquisition. There are four class tests. The gross asset test - a ratio of the gross assets of the target and the acquirer. The profits test - a ratio of the profits (after deducting all charges except taxation) attributable to the assets of the target and the acquirer. The consideration test - a ratio of the consideration for the deal and the aggregate market value of all ordinary shares (excluding treasury shares) of the acquirer. The gross capital test - a ratio of the gross capital of the target and the acquirer. Shareholder approval is required for a Class 1 acquisition, which is a transaction where at least one class test percentage ratio is $25 \%$ or more.

Second, reverse takeovers also need to be approved by shareholders (LR 5.6). The UK Listing Rules define a reverse takeover as a transaction where any class test percentage ratio is $100 \%$ or more; or which in substance results in a fundamental change ${ }^{11}$ in the business or in a change in board or voting control of the issuer. This does not mean that reverse takeovers are Class 1 acquisitions. Circulars sent to shareholders explain the reason for why approval is required, i.e. the deal is a reverse takeover or a Class 1 acquisition. There is also a mandatory approval of reverse takeovers under Rule 14 of AIM Rules (2016).

Third, acquirer firms announcing a related-party acquisition are also required to obtain shareholder approval. A related-party transaction is a transaction (any class test percentage ratio is above $5 \%$ ) between a company and a related-party, where the related-party means a substantial shareholder or director of the company, or a person who may exercise significant influence $^{12}$ and an associate of these three. The related-party cannot vote (LR 11). 
Appendix B - Definition of variables

\begin{tabular}{ll}
\hline Variables & \multicolumn{1}{c}{ Definition } \\
\hline Dissent & The number of votes 'against' as a percentage of total votes cast on M\&As \\
Dissent 2 & The number of votes 'against' as a percentage of total votes that could be cast on M\&As \\
High Dissent & Dummy variable set to 1 if Dissent is higher than the mean Dissent, 0 otherwise \\
DissentDRR & The number of votes 'against' as a percentage of total votes cast on DRRs \\
CAR $(-1 ; 1)$ & $\begin{array}{l}\text { The 3-day cumulative abnormal returns around transactions calculated using the event-study } \\
\text { methodology based on the market model. The market return used is the return on FTSE All } \\
\text { Share Index. The estimation period used to calculate } \alpha \text { and } \beta \text { parameters of the model is } \\
\text { trading } 150 \text { days }(-180,-30) \text { relative to the announcement }\end{array}$
\end{tabular}

Firm Size

Logarithm of book value of sales

$R O A$

The ratio of net income over book value of total assets

Tobin's $q$

Market value of total assets divided by book value of total assets, where market value of total assets is calculated as book value of total assets minus book value of common equity plus market value of common equity

Cash/Assets Cash and cash equivalents divided by book value of totals assets

Leverage

The ratio of total debt over book value of total assets

Excess Total Comp

Difference between observed CEO total compensation and predicted CEO total compensation (residual of the OLS regression of CEO total compensation against its economic, governance, and ownership determinants together with year and industry controls) as in Core, Guay, and Larcker (2008) and Feito-Ruiz and Renneboog (2017)

Excess Cash Comp

Difference between observed CEO cash compensation and predicted CEO cash compensation (residual of the OLS regression of CEO cash compensation against its economic, governance, and ownership determinants together with year and industry controls) as in Core, Guay, and Larcker (2008) and Feito-Ruiz and Renneboog (2017)

BoardOwn

Percentage of shares owned by the board of directors

OwnConc

The percentage ownership of the largest shareholder who is not a board member

Board Size

Log of the number of directors on the board

Non-Exec

Percentage of non-executive directors on the board

Gender

Number of female directors on the board

CEO Age

Log of the age of the CEO at the financial year end

Rel.Size

Deal size divided by the market value of the acquirer

Diversifying

Cash-payment

Dummy variable set to 1 if acquirer and target firms' 2-digit SIC codes are different, 0 otherwise

Friendly

Dummy variable set to 1 if a bid is financed by cash only, 0 otherwise

Dummy variable set to 1 if a bid is friendly, 0 otherwise 


\title{
Notes
}

\begin{abstract}
1 Royal Bank of Scotland shareholders have overwhelmingly rejected (90.42\% against) the bank’s remuneration report because of $£ 703,000$ pension payment to outgoing CEO Fred Goodwin alongside the bank's $£ 40 \mathrm{bn}$. loss. It is the lowest vote in favour of a remuneration report in the UK corporate history, according to Manifest, a voting adviser (Financial Times 2009). See Gregory-Smith, Thompson, and Wright (2014) for more examples.
\end{abstract}

2 In our sample the resolution that received the highest level of dissent, 19.7\%, is the related-party acquisition of Prodeco Businesses by Xstrata from Glencore announced on 29 January 2009. Eight deals received significant shareholder backlash, i.e. more than 10\% dissent (Manifest 2009).

3 Manifest Ltd is a UK-based proxy voting agency that provides corporate governance and proxy voting services and data for institutional investors, company advisors and academics. Some of the studies that have used data from Manifest are Conyon and Sadler (2010), Gregory-Smith, Thompson, and Wright (2014), Stathopoulos and Voulgaris (2016).

4 For deals for which we do not have data on the number of votes, there is only one deal blocked by shareholders on EGM. It is a Class 1 acquisition of Innicor Subsurface Technologies by Sondex plc announced on 21 September 2006. However, the deal was blocked because the board of directors of Sondex has determined to amend its recommendation and strongly advised that shareholders vote against the deal. As the company reported, this was because of the poor third quarter financial results of Innicor and certain other factors. In all other cases, managers' recommendations are in favour of the proposed acquisitions.

5 G4S plc, which announced a reverse takeover of ISS A/S on 17 October 2011, received negative market reaction of -21.6\%/-10.4\% as measured by AR/CAR(-1;1). Despite the negative returns, the board of directors decided to carry on with the deal. Later, they reported that after consulting with their shareholders to listen carefully to concerns regarding the acquisition and they concluded that it was inappropriate to proceed.

6 We thank an anonymous referee for suggesting using excess compensation in explaining Hypothesis 2.

7 We replace OwnConc, measured as the percentage ownership of the largest shareholder who is not a board member, with $O w n C o n c 2$ as an alternative measure of ownership concentration in all regressions. OwnConc 2 is measured as the ratio of the sum of shares held by large shareholders (shareholdings exceeding $3 \%$ cut-off level are disclosed in annual reports). We find no difference in the results.

8 According to Manifest (2009), "dissent level of greater than 5\% should be cause for concern for a company and 10\% would constitute what the press would be apt to call a shareholder backlash". The deal with the highest dissent (19.7\%) is the related-party acquisition of Prodeco Businesses by Xstrata from Glencore announced on 29 January 2009. Since Glencore was a substantial shareholder of Xstrata only independent shareholders were allowed to vote. Shareholders revolted against a preferential treatment given to Glencore in the form of a call option to buy the business back after one year and voted against the deal (The Guardian, 2009). The second deal with the highest dissent (17.6\%) is a Class 1 acquisition of the Trafford Centre Group owned by Peel Holdings by CSC Group announced on 25 November 2010. Simon Property Group and a group of investors thought that an all-share deal with Peel Holdings, which is controlled by tycoon John Whittaker, would give him too much control in the company after completion (The Telegraph, 2011). Nonetheless, the two deals were approved.

9 There is however evidence in the extant literature which contradicts the argument that diversification is always value destroying (see e.g. Ataullah et al. 2014).

10 For the few firms from 1997 to 2015 for which there is no data on the total number of voting rights we collect the number of ordinary shares from annual reports, assuming 'one share one vote' standard, and use it as the total number of votes that could be cast.

11 The FCA considers that the following factors are indicators of a fundamental change: (1) the extent to which the transaction will change the strategic direction or nature of its business; or (2) whether its business will be part of a different industry sector following the completion of the transaction; or (3) whether its business will deal with fundamentally different suppliers and end users (LR, p. 20).

12 In relation to a listed company, a person or entity which exercises significant influence over that listed company (LR, Appendix 1, p. 15). 